\title{
The effect of changing sea ice on the physical vulnerability of Arctic coasts
}

\author{
K. R. Barnhart ${ }^{1,2}$, I. Overeem ${ }^{2}$, and R. S. Anderson ${ }^{1,2}$ \\ ${ }^{1}$ Department of Geological Sciences, University of Colorado at Boulder, Boulder, CO, USA \\ ${ }^{2}$ Institute of Arctic and Alpine Research, University of Colorado at Boulder, Boulder, CO, USA \\ Correspondence to: K. R. Barnhart (katherine.barnhart@colorado.edu)
}

Received: 14 April 2014 - Published in The Cryosphere Discuss.: 7 May 2014

Revised: 31 July 2014 - Accepted: 20 August 2014 - Published: 26 September 2014

\begin{abstract}
Sea ice limits the interaction of the land and ocean water in the Arctic winter and influences this interaction in the summer by governing the fetch. In many parts of the Arctic, the open-water season is increasing in duration and summertime sea-ice extents are decreasing. Sea ice provides a first-order control on the physical vulnerability of Arctic coasts to erosion, inundation, and damage to settlements and infrastructures by ocean water. We ask how the changing sea-ice cover has influenced coastal erosion over the satellite record. First, we present a pan-Arctic analysis of satellite-based sea-ice concentration specifically along the Arctic coasts. The median length of the 2012 open-water season, in comparison to 1979 , expanded by between 1.5 and 3-fold by Arctic Sea sector, which allows for open water during the stormy Arctic fall. Second, we present a case study of Drew Point, Alaska, a site on the Beaufort Sea, characterized by ice-rich permafrost and rapid coastal-erosion rates, where both the duration of the open-water season and distance to the sea-ice edge, particularly towards the northwest, have increased. At Drew Point, winds from the northwest result in increased water levels at the coast and control the process of submarine notch incision, the rate-limiting step of coastal retreat. When open-water conditions exist, the distance to the sea ice edge exerts control on the water level and wave field through its control on fetch. We find that the extreme values of water-level setup have increased consistently with increasing fetch.
\end{abstract}

\section{Introduction}

Arctic coasts are at the mercy of sea ice: the processes of erosion and sedimentation are limited by the presence or absence of nearshore sea ice. Shore-fast sea ice limits erosion, suspension, and transport of sediment by wave action in the nearshore water. In regions dominated by ice-rich permafrost, erosion of the coastline is controlled by the delivery of heat to the coast, which is also influenced by sea-ice cover. Sea ice does not exclusively prevent erosion; land-fast sea ice in shallow water can incorporate sediment and carry it away as sea-ice drifts (Eicken et al., 2005), ice pile-up and rideup can transport sediment (Kovacs and Sodhi, 1980), and ice keels can resuspend and transport shelf sediment (Rearic et al., 1990; Héquette et al., 1995). But the rates of these sediment transport processes are smaller than those driven by the nearshore ocean. The sea ice is thus the first-order link between Arctic coasts and the nearshore environment.

The Arctic environment is changing, and this has resulted in thinner sea ice and more extensive summertime open water (IPCC, 2013). We ask how the changing sea-ice characteristics have manifested at the coast.We consider the physical vulnerability as the inability of a system to resist change. In the context of Arctic coasts, physical vulnerability results from the interplay between resisting and forcing factors, such as strength of the terrestrial substrate (resisting) and the passage of storms during times of open water (forcing). We can also cast this dichotomy in terms of static and dynamic factors: the lithology and geomorphology of the coastline are static, while the length of the open-water season, the distance to the sea-ice edge, the magnitude and frequency of storms, and the water temperature are all dynamic. 
Coastal erosion or deposition results from the convolution of the nearshore water and sea-ice dynamics, the nature of the terrestrial substrate, and geomorphic processes that govern material removal and distribution. Ultimately, the nearshore wave field and water level provides the energy to do work on the landscape. Depending on the geomorphology of a coastline, the wave field or water level may be more important in governing its physical vulnerability. For example, low-lying areas subject to inundation may be most impacted by waterlevel setup associated with large storm surges, whereas sandy beaches and barrier islands will be influenced by changes in the wave field. Along ice-rich permafrost coastal bluffs, the length of time in which the nearshore water is set up to the base of the bluff is most significant (Barnhart et al., 2014). In other environments, like the large Arctic deltas, the processes of erosion are different, but exposure to some combination of the water level and wave field is likely important. With the exception of damage by sea-ice shove, the processes described are prevented by the sheath of land-fast sea-ice cover in the winter.

The changes in the duration of Arctic sea-ice cover exert a first-order control on the physical vulnerability of the Arctic coastline. We show that, when open water is present, the sea ice still exerts influence by controlling (1) the fetch, or the distance over which wind can interact with the nearshore water creating storms surge and waves, and (2) the area over which the ocean can absorb incident solar radiation. The combination of environmental change in the Arctic and the importance of sea ice in limiting geomorphic processes motivates a process-based understanding of the links between sea ice and coastal processes. Here, we focus on the impact of changing sea ice, particularly the increased fetch, on the nearshore water conditions.

We use satellite-based observations of sea ice to construct a whole-Arctic analysis of the changing open-water season along the Arctic coastline. We then combine this analysis with observations of the local wind field and the nearshore water level and wave field to examine the changing environment at one site - Drew Point, Alaska - through the lens of the changing sea-ice season. The Drew Point area is characterized by exposed ice-rich permafrost bluffs that erode rapidly when water is set up above the base of the bluffs. It has experienced both changes in the open-water season and an increase in coastal-erosion rates. Our goal is to understand the extent to which changes in sea-ice cover and the nearshore conditions relate to coastal erosion. We use a numerical model for nearshore storm surge and the wave field to reconstruct storm surge and waves for the period 1979-2012 and to explore the sensitivity of the nearshore conditions to changing fetch. We then analyze the 1979-2012 hindcast of environmental conditions to identify how the changes in the sea-ice cover manifest in the nearshore conditions.

\section{Arctic climate and Arctic coasts}

The Arctic environment is warming (Comiso, 2003; Blunden and Arndt, 2012). The frequency and intensity of storms are anticipated to increase, particularly in the autumn and winter (ACIA, 2004; Manson and Solomon, 2007; Clow et al., 2011). Observed Arctic storminess is characterized by large inter-annual variability, and no long-term trends are detectable in wind records from 1950-2000 (Atkinson, 2005). However, an analysis of the National Centers for Environmental Prediction/National Center for Atmospheric Research (NCEP/NCAR) reanalysis by Sepp and Jaagus (2011) found that the number of cyclones that entered the Arctic basin had increased significantly $(p<0.05$ over the period 19482002), while no significant trends were found in the number of cyclones that had formed within the Arctic.

In conjunction with decreased sea-ice extent (Serreze et al., 2007), decreasing sea-ice thickness and age (Maslanik et al., 2007, 2011), and increasing duration of the open-water season (Stammerjohn et al., 2012), the changes in storminess have the potential to result in increased storm surge and wave action and increasing vulnerability of Arctic coasts to geomorphic change, inundation, and damage to infrastructure. These environmental changes impact not only the duration of time over which the ocean and land can interact, but also the aerial extent of open water which provides greater fetch and associated increased surge and wave climate (Lintern et al., 2011; Overeem et al., 2011).

The average rate of coastal erosion for the portion of the Arctic coast considered in the Arctic Coastal Dynamics database is $0.5 \mathrm{~m} \mathrm{yr}^{-1}$ (Lantuit et al., 2012). This project analyzed $\sim 25 \%$ of the Northern Hemisphere permafrost impacted coastline and found coastal-erosion rates that reach $8.4 \mathrm{~m} \mathrm{yr}^{-1} ; 89 \%$ of the segments have erosion rates below $2 \mathrm{~m} \mathrm{yr}^{-1}$. The highest rates of Arctic coastal erosion occur in ice-rich permafrost bluffs, which only occur along cold coasts. Elsewhere in the world, some of the most extreme rates of coastal erosion occur on sandy coasts. For example, erosion rates in Mississippi, Texas, and Louisiana reach up to $12 \mathrm{~m} \mathrm{yr}^{-1}$ (Morton et al., 2005), and most of the globe's sandy coastlines have retreated since 1900 (Bird, 1985).

A comparison of erosion rates along sandy coasts and ice-rich permafrost bluffs is not that meaningful. There is no good analogy for permafrost bluffs outside of the Arctic - they are highly competent when frozen, and, in that regard, are similar to rocky coastlines. However, unlike rocky coastlines, permafrost bluffs can thaw and thereby rapidly lose all competence. Rocky coastlines erode at rates of order $10 \mathrm{~cm} \mathrm{yr}^{-1}$ (e.g., Moore and Griggs, 2002, measured over 41 years), while cliffs in softer material erode at up to $4.5 \mathrm{~m} \mathrm{yr}^{-1}$ (e.g., Brooks and Spencer, 2010, measured over 125 years). Both erode much more slowly than permafrost bluffs. 
A. Projected value of the number of open water days per year for 1979
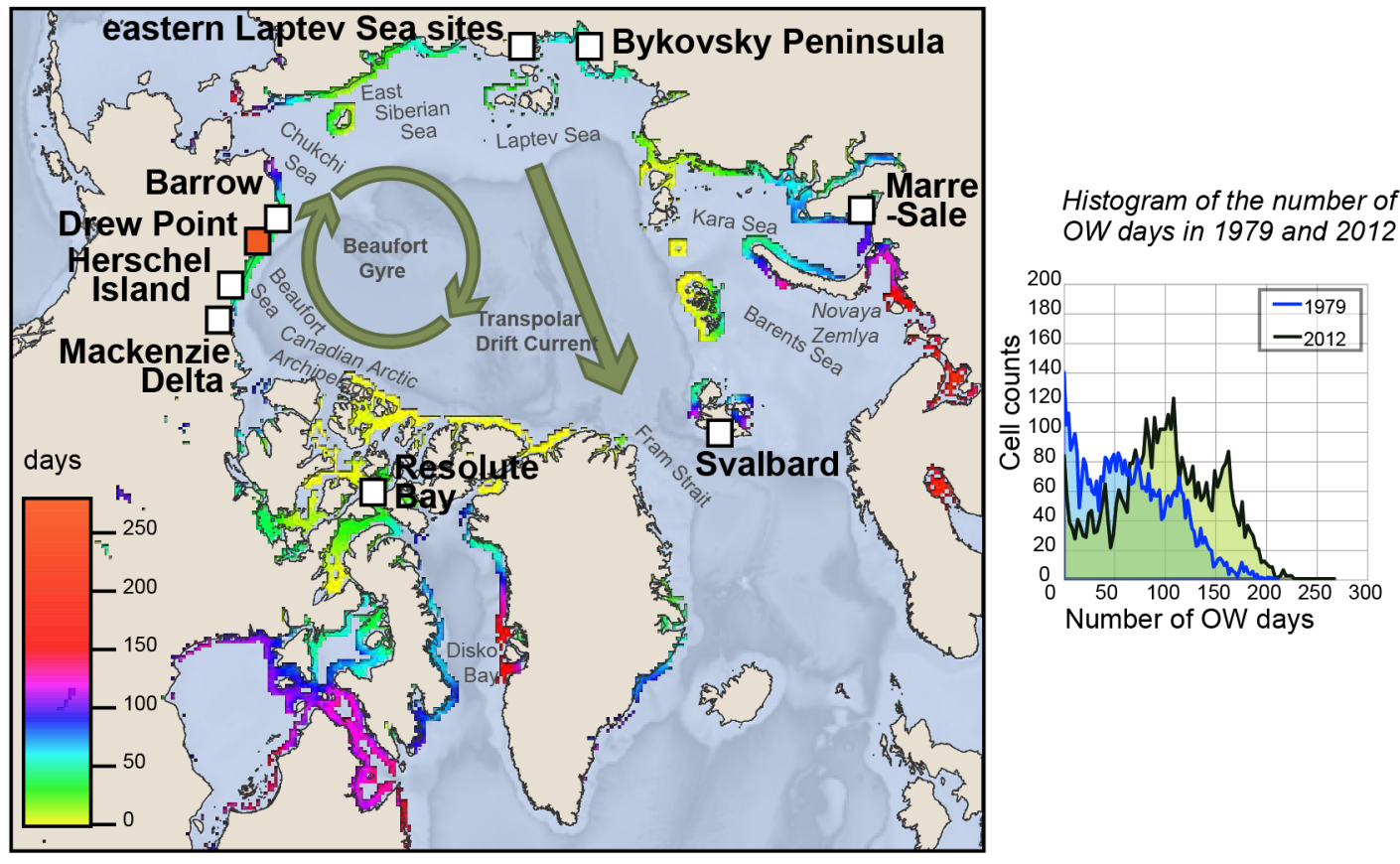

B. Rate of change of the number of sea ice free days (1979-2012)

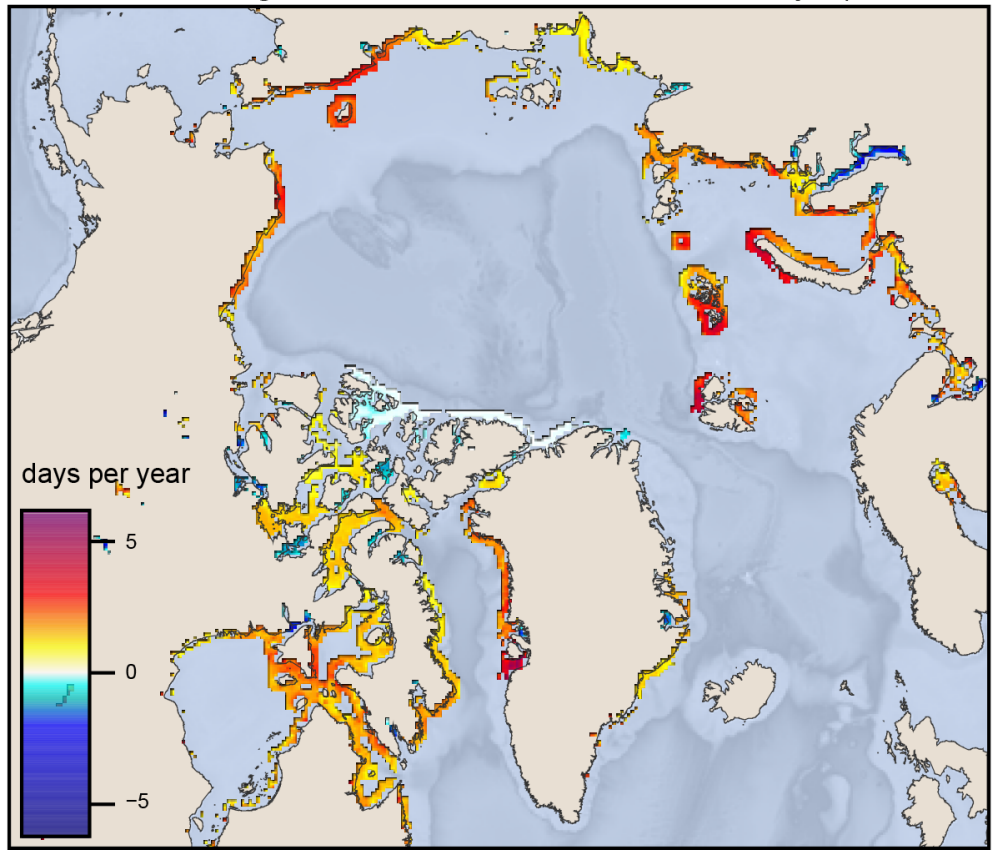

Histogram of the rate of change in open water (1979-2012)

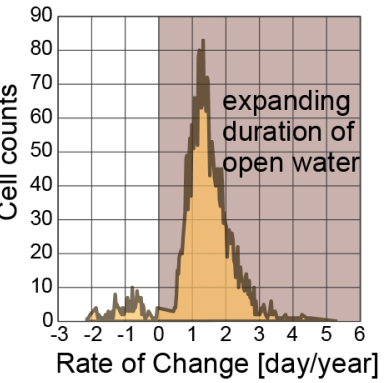

Figure 1. Maps of sea-ice change for coastal cells across the whole Arctic. We calculated the number of open-water days per year - defined as sea-ice concentration less than 15\% - for the period 1979-2012 for each nearshore cell in which sea ice is shore fast (sea ice present for more than 60 days) for at least 20 years. We fit a linear trend line to number of open-water days. (a) The value of the trend line constraining the projected number of open-water days in 1979. The inset histogram shows the distribution of the number of open-water days in 1979 and 2012. (b) The resulting rate of change in the number of open-water days per year (slope of the trend line). Only cells with $p$ values of less than 0.05 are shown. Typical rates on the Beaufort Sea coast of Alaska are 1.5-2.5 day $\mathrm{yr}^{-1}$. Inset histogram shows the distribution of the rate of change. Underlying bathymetry from The GEBCO 08 Grid (version 20100927, http://gebco.net). 
A. Slope of trendline for the first day of continous open water
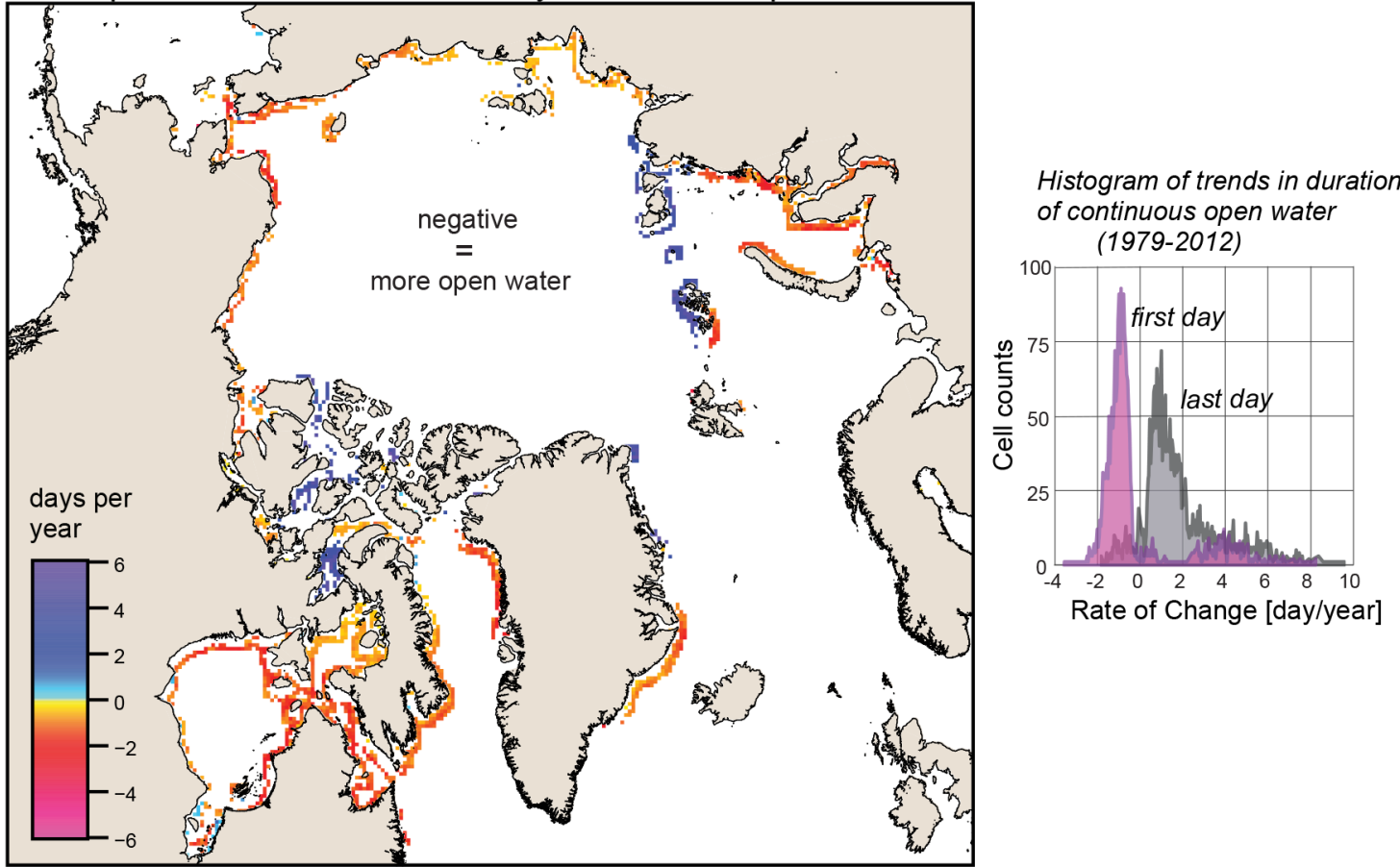

B. Slope of trendline for the last day of continous open water

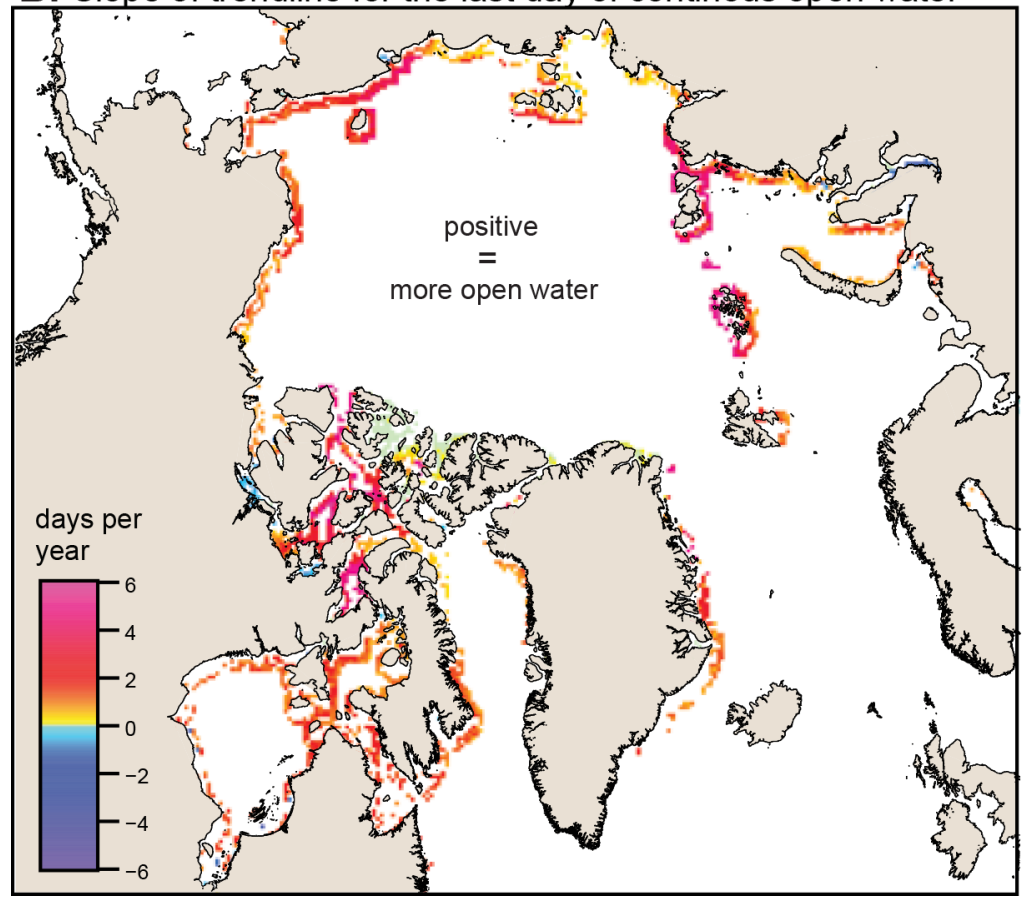

Histogram of trends in duration of continuous open water (1979-2012)

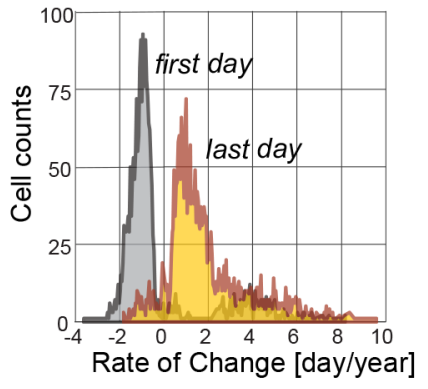

Figure 2. Trends in the first (a) and last (b) day of continuous open water across the Arctic. Inset histograms show the distribution of trend line values. Only cells with $p$ values of less than 0.05 are shown. The rate of expansion into the fall is greater than in the spring. There are more days with significant trends in the last day of open water than the first. Note that the color axis has been flipped so that blue represents expanding open water in both panels. 


\section{Overview of the Drew Point coast}

Drew Point is located along the most rapidly eroding segment of the central-western Alaskan Beaufort Sea coast. At Drew Point, the length of the open-water season over the satellite

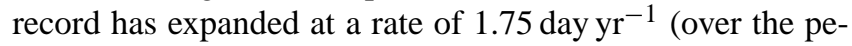
riod 1979-2009, Overeem et al., 2011, also Fig. 1). The duration of the open-water season over this time period has doubled from $\sim 45$ days of open water per year to $\sim 95$ days (Overeem et al., 2011). Open water conditions currently begin in mid-July to early August and end in late September to early October. The duration of open-water conditions for the period 1979-2009 expanded faster into the autumn than into the spring (Overeem et al., 2011, also Fig. 2). Autumn is typically stormier than summer in the Beaufort Sea region. Over the period 1950-2000, an average of 8.5 storms (wind speeds greater than $10 \mathrm{~m} \mathrm{~s}^{-1}$ for a duration of $48 \mathrm{~h}$ ) occurred in September and October combined, whereas an average of 6.5 storms occurred in July and August (Atkinson, 2005).

To the north of Drew Point, the Beaufort Shelf slopes north at $\sim 0.001 \mathrm{~m} \mathrm{~m}^{-1}$ (Rickets, 1953; Greenberg et al., 1981) and is roughly uniform along the coastline. The mean tidal range at the nearest National Oceanic and Atmospheric Administration (NOAA) tide gauge station (Prudhoe Bay $240 \mathrm{~km}$ to the ESE) is $15 \mathrm{~cm}$ for daily to monthly cycles, which are superimposed on a yearly tidal cycle with a range of $66 \mathrm{~cm}$ with a peak in late July [NOAA Tide Gauge Station 9497645]. The local wind field is dominated by winds from the east and northeast with a smaller secondary maximum from the west (Urban and Clow, 2013, and Fig. 3a and b). When surface winds are from the west, water is pushed towards the shore by Ekman transport (Fig. 4). Winds from the east set down water levels. These observations are consistent with bathystrophic surge theory (e.g., Dean and Dalrymple, 1991). Winds from the west are typically associated with the passage of synoptic-scale storms. In the spring and autumn, the easterly winds are consistent with winds coming off the Beaufort Sea High, a persistent atmospheric feature characterized by high sea-level air pressure (Serreze and Barrett, 2011).

Acceleration of coastal retreat at Drew Point and along the $70 \mathrm{~km}$ coastline to the west has accompanied the change in the length of the open-water season. The rate of area loss more than doubled from $0.48 \mathrm{~km}^{2} \mathrm{yr}^{-1}$ for 1955 1985 to $1.08 \mathrm{~km}^{2} \mathrm{yr}^{-1}$ for $1985-2005$ (Mars and Houseknecht, 2009). Jones et al. (2009) found that coastalerosion rates increased from $6.8 \mathrm{~m} \mathrm{yr}^{-1}$ for $1955-1979$ to $8.7 \mathrm{~m} \mathrm{yr}^{-1}$ for $1979-2002$ and $13.6 \mathrm{~m} \mathrm{yr}^{-1}$ for 2002-2007. Barnhart et al. (2014) report that the mean erosion rate over a $7 \mathrm{~km}$ stretch of the central-west Beaufort Sea coast just east of Drew Point was $15 \mathrm{~m} \mathrm{yr}^{-1}$ (2008-2011) and $19 \mathrm{~m} \mathrm{yr}^{-1}$ (2011-2012). Early work in the region documented coastal retreat rates that locally reached $18 \mathrm{~m} \mathrm{yr}^{-1}$ (during the period 1950-1980) (Reimnitz et al., 1985, 1988). More re-

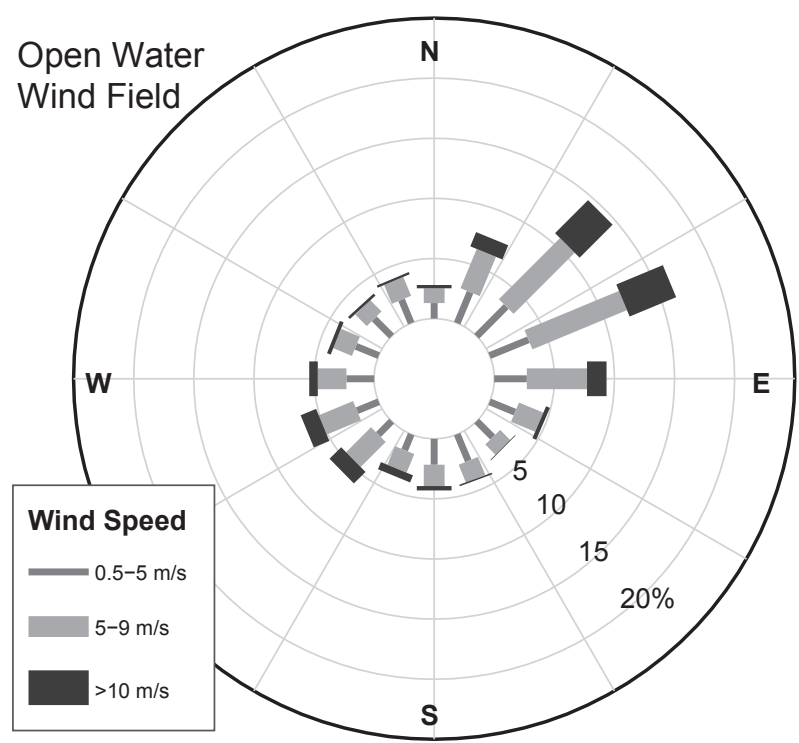

Figure 3. Wind field at Drew Point during the open water season. The wind field is dominated by wind from the ENE, but shows a smaller secondary maximum from the WSW (data from Urban and Clow, 2013).

cently Wobus et al. (2011) reported local rates that reached $30 \mathrm{~m} \mathrm{yr}^{-1}$ in the summer of 2008 .

At Drew Point the process of erosion is dramatic. Standing between the low-relief coastal plain and the Beaufort Sea are $4 \mathrm{~m}$ high bluffs. The bluffs are composed of icerich permafrost ( 50 to $80 \%$ by mass), organic material, and silt- and clay-sized inorganic material (Wobus et al., 2011). The permafrost depth extends to $320 \mathrm{~m}$ into the subsurface (http://www.gtnp.org/), the active layer is $30-50 \mathrm{~cm}$ deep, and the mean annual surface temperature ranges from -8.5 to $-6.5^{\circ} \mathrm{C}$ (1998-2011 Urban and Clow, 2014). The ground is dissected by massive ice wedges that extend around $4 \mathrm{~m}$ into the subsurface. The bluffs erode through the process of failure on an ice wedge after water levels are set up to the base of the bluffs resulting in a notch carved at the base of the coastal bluff by submarine erosion (Kobayashi, 1985; Kobayashi et al., 1999; Hoque and Pollard, 2009; Wobus et al., 2011; Barnhart et al., 2014). This failure creates a toppled block that subsequently rotates towards the sea as it degrades by the melting of interstitial ice. The process of coastal erosion in this area is most sensitive to water levels that are set up above the base of the bluffs (Barnhart et al., 2014).

\section{Data}

Our analysis is based on three publicly available data sets: pan-Arctic sea-ice concentrations; meteorology from Drew Point and Barrow, Alaska; local field observations of the 
A. Wind Direction vs. Water Set Up B. Wind Speed vs. Water Set Up
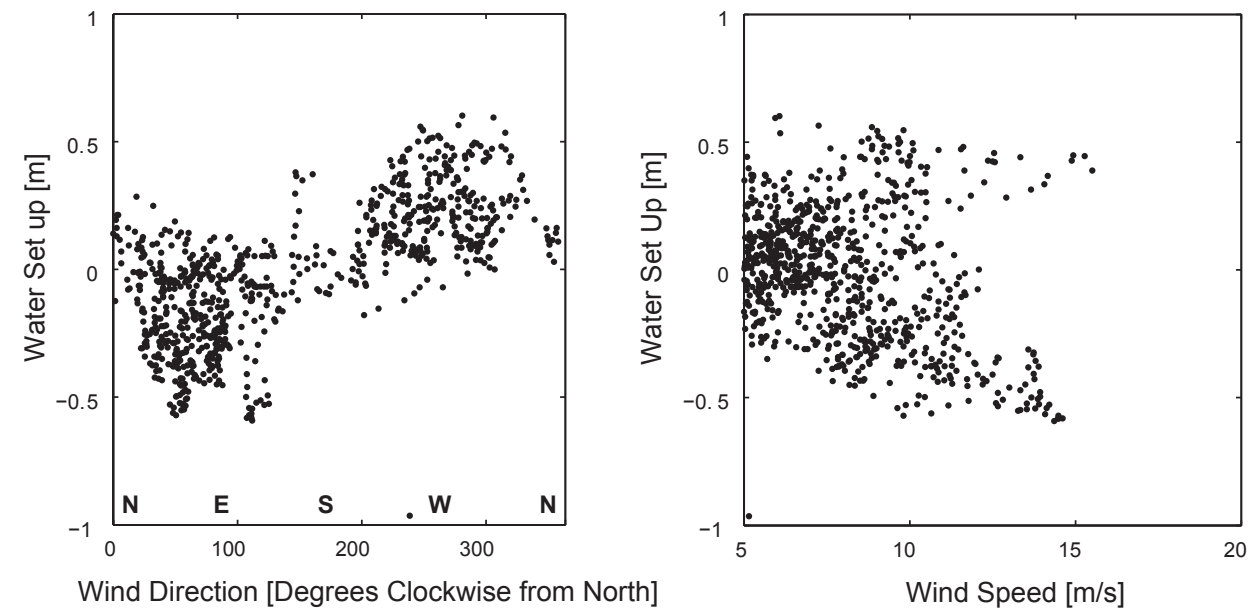

C. Wind Direction vs. Wave Height

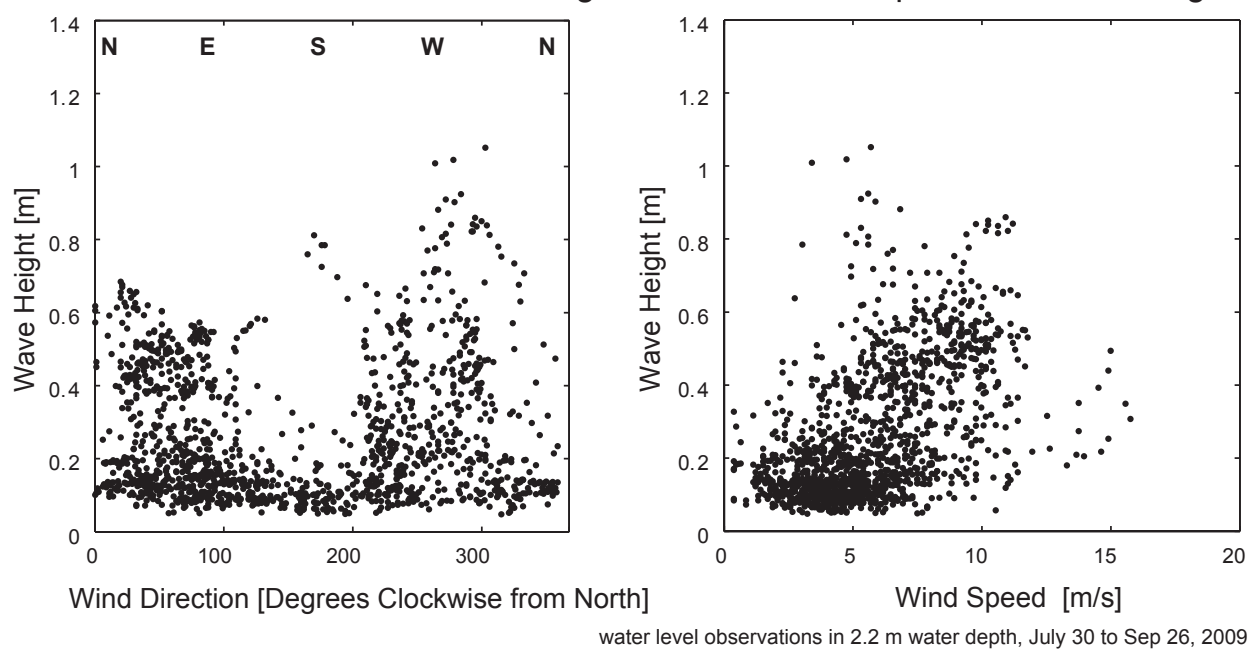

Figure 4. Relationship between wind field and nearshore conditions at Drew Point. Winds from the east set water levels down, whereas winds from the west set water levels up (a). As wind speed increases, the magnitude of setup or set down is increased (b). Wave height increases with wind from the east or west (c) and increases with increasing wind speed (d).

water level and wave field collected in the summers of 2009 and 2010 at Drew Point.

Arctic-wide sea ice: the concentration of sea ice at a $25 \mathrm{~km}$ grid scale is given by the Nimbus7 SMMR/SSM/I and DMSP SSMI Passive Microwave Sea Ice Concentrations (referred to throughout the text as "sea-ice concentration" or SIC) derived from brightness temperature (Cavalieri et al., 1996). This data set is available from the National Snow and Ice Data Center (NSIDC, http://nsidc.org/data/nsidc-0051.html), and is used to determine open-water conditions and locate the sea-ice edge.

Drew Point wind speed and direction: wind speed and direction have been observed by the United States Geological Survey (USGS) at Drew Point since 7 August 2004 (Urban and Clow, 2013). On 29 June 2008, a second sta- tion was installed closer to the coast (http://data.usgs.gov/ climateMonitoring/station/show/5, called CU Drew Point Site). Both stations are Campbell Scientific meteorological stations that measured wind speed and direction every $30 \mathrm{~s}$, recording an average value once per hour.

Barrow wind speed and direction: the hourly wind speed and direction measured at Barrow (http://www.esrl.noaa.gov/ gmd/obop/brw/) are used to calculate wind setup and wave field. Wind speed and direction measured at Barrow are adjusted using the transfer function developed by Overeem et al. (2011) to relate the wind field at Barrow to that at Drew Point. This transfer function was optimized for winds greater than $5 \mathrm{~m} \mathrm{~s}^{-1}$ during open-water conditions, and is based on comparison of wind speed and direction measured at Barrow with those measured at the CU Drew Point station over 
the time period June 2008-September $2010\left(R^{2}=0.8\right)$. We also examined the wind record collected by NOAA at Prudhoe Bay (NOAA station \#9497645) and found that the wind records at Barrow, Drew Point, and Prudhoe Bay were all visually similar.

Drew Point water level and wave field: the water level, significant wave height, and wave period were measured with wave-field loggers, custom-built by Tim Stanton at the Naval Postgraduate School. Four wave loggers were deployed in 2009 in depths ranging from 1.9 to $6.8 \mathrm{~m}$ (up to $9 \mathrm{~km}$ from the shore). One wave logger was deployed in 2010 at a water depth of $88 \mathrm{~cm}$. These observations are summarized by Barnhart et al. (2014).

\section{Changes in the open-water season at the coast}

We present three novel analyses to illustrate how the openwater season has changed along the Arctic coastline. We calculate the change in the number of open-water days at each coastal cell $(25 \mathrm{~km}$ cell size $)$ over the satellite record, and document how open water has expanded into the early summer and fall. We document how fetch, over the length of the open-water season, has changed at Drew Point, and examine how this is related to the duration of the open-water season. Finally, we employ a storm-surge and wave model to reconstruct the nearshore conditions at Drew Point for the period 1979-2012, and use the modeled water-level and waveheight histories to produce quantitative metrics for the water exposure of the coastal bluffs at Drew Point.

\subsection{Whole-Arctic analysis}

The duration of the open-water season controls the length of time that open water can interact with the coast to accomplish geomorphic work. We calculate the number of openwater days at each nearshore cell for the period 1979-2012. The spatial extent of our analysis, meant to represent the nearshore zone, is the ocean pixel adjacent to the NSIDC landmask and the next two closest water pixels. The spatial resolution of the sea-ice data set is $25 \mathrm{~km}$ and thus this represents the $\sim 75 \mathrm{~km}$ of water closest to the shore. Open water is defined as sea-ice concentrations less than $15 \%$, a standard threshold for identifying the sea-ice margin (see Meier and Stroeve, 2008). The definition of the beginning and the end of the open-water season is tricky because, in some areas, sea ice retreats rapidly, while, in other areas, sea ice may retreat and then be blown back in repeatedly. Here, we present an analysis of the total number of open-water days per year.

We examine only cells in which sea ice is shore fast here defined as greater than 60 days all with $80 \%$ sea-ice concentration or higher. If one of these cells has an openwater season for more than 20 of the 33 years for which we have satellite coverage, we calculate a linear fit to the history of open-water day per year. Figure 1 shows both the slope and the intercept in 1979 of the significant trend lines ( $p$ value $<0.05$ ); a cell is left blank if the trend line is not significant. We present the intercept of the trend line in 1979 rather than the 1979 value itself to account for the large interannual variability in the sea-ice season.

The sea-ice concentration data set is resolved at $25 \mathrm{~km}$, which results in some mixed land-ocean/sea-ice pixels at the coastline. Thus, the data set has inherent limitations because of land-ocean contamination. However, Overeem et al. (2011) examined the sea-ice concentration product used in this study relative to high spatial resolution Interactive Multisensor Snow and Ice Mapping System $(4 \mathrm{~km})$ data and MODIS imagery $(250 \mathrm{~m})$, and found that the sea-ice product used in this study was adequate. We examine both the pixel closest to the land, as well as the two next closest water pixels (which should not contain any land contamination).

The length of the open-water season in 1979 (Fig. 1a) decreases with increasing latitude. The distribution of the number of open-water days in 1979 and 2012 illustrates the expansion of the length of the open-water season (Fig. 1a inset). Although a few coastal cells show a decrease in the length of open water, most coastal cells show an increase (Fig. 1b). The trends in expansion of open water at the coast vary throughout the Arctic. The Beaufort and East Siberian Sea regions, northern Novaya Zemlya, Svalbard, Franz Josef Land, and Disko Bay show a rapid increase in the number of open-water days per year, while the Canadian Arctic Archipelago shows little to no trend (Fig. 1b). The difference between Beaufort and East Siberian Sea regions and the Canadian Arctic Archipelago pattern is controlled by the large-scale patterns of sea-ice drift, which move sea ice clockwise around the Beaufort Gyre and from the Siberian and Alaskan coast toward the Transpolar Drift Current and out Fram Strait (Jones, 2001; Serreze and Barry, 2005). Smaller surface currents move sea ice from the Barents Sea into the Transpolar Drift Current (Jones, 2001; Serreze and Barry, 2005).

We also determine trends in the first and last day of continuous open water (Fig. 2). The open-water season is expanding asymmetrically, with faster rates of expansion into the fall than the spring. This is significant for coastal vulnerability because of variability in the storm climate in the spring and the fall (Atkinson, 2005). Expansion into the mid-summer provides open water at times of higher insolation. This results in higher water temperatures, which impact coastal-erosion rates in regions with high ice content.

\subsubsection{Spatial patterns of sea-ice change, coastal erosion, and ice content}

While we cannot address the details of the changing nearshore environment (or even the directional fetch) across the whole Arctic, we can consider the changing length of open-water days (Fig. 1) in the context of some of the other key factors that govern physical vulnerability. We present 
whole-Arctic maps of coastal-erosion rate, backshore elevation, and ground-ice content compiled as part of the Arctic Coastal Dynamics project (Fig. 5) (Lantuit et al., 2012). Particularly rapid erosion $\left(>2 \mathrm{~m} \mathrm{yr}^{-1}\right)$ occurs in the Beaufort, East Siberian, and Laptev Sea regions. Lantuit et al. (2012) found that coastal-erosion rates are higher on unlithified coastal segments, that erosion rates correlated positively but weakly with ground-ice content, and even more weakly with backshore elevation.

We compare coastal-erosion rates and ice content from Lantuit et al. (2012) for coastal database segments with erosion rates greater than $0.1 \mathrm{~m} \mathrm{yr}^{-1}$ with the 2012 number of open-water days (Fig. 6). The relationship between the duration of open water, the erosion rate, and ice content is not simple. It appears that, on up to $\sim 220$ open-water days, the longer the open-water season and the higher the ice content, the greater the capacity for high coastal-erosion rates. Still, coastal segments with short open-water seasons and high erosion rates, and segments with high ice content, long open-water seasons, and low erosion rates exist. Figure 6 appears to highlight the limited behavior of coastal vulnerability; rapid erosion along segments with high ice content and long open-water seasons will only occur if a storm passes.

\subsubsection{Well-studied Arctic coasts}

Before focusing on Drew Point, Alaska (Sect. 3), we discuss the whole-Arctic results in the context of the other wellstudied coastlines in Russia, the Canadian Beaufort Sea, the Canadian Arctic Archipelago, and Svalbard. Multi-temporal studies are required to identify changes in coastal processes and evaluate connections with forcing changes, yet very few areas have multi-temporal observations (Lantuit et al., 2013). We expect to see a relationship between sea-ice change and coastal-erosion rate in places with high erosion rates and places with large increases in the length of the open-water season.

Multi-temporal observations for 1984-2002 are available at Marre-Sale, a site along the Kara Sea with 10-30 m high coastal bluffs with ice content of $20-60 \%$ (Vasiliev et al., 2005). At this site, erosion occurs by thermal erosion at the base of the cliff (Vasiliev et al., 2005) and the number of open-water days per year has increased by $1.5-3$ day $\mathrm{yr}^{-1}$. Erosion rates are best correlated with total wave energy that has not increased through time but instead shows a maximum in the late 1980s (Vasiliev et al., 2005).

At the Bykovsky Peninsula on the Laptev Sea, a site with high ice content characterized by either coastal cliffs or lowlying thermokarst depressions, where we find the number of open-water days, has increased at $0.5-1$ day $\mathrm{yr}^{-1}$. Coastalerosion rates that were measured between 1951 and 2006 show no trend in time or relation to storm records (Lantuit et al., 2012). Coastal erosion rates along the Byovsky Peninsula coastline are strongly affected by the lithology and geomorphology with the highest coastal-erosion rates occurring in depressions created by the thawing of ice-rich permafrost and the lowest rates occurring along sand bars (Lantuit et al., 2012).

Further east on the Laptev Sea, three sites with high ice content show increases in mean annual erosion rates and spatial variability associated with lithology and geomorphology (measured between 1965 and 2011) (Günther et al., 2013). In this area, there are fewer coastal cells with significant trends over the 1979-2012 time period, but those that are significant give trends of $0.5-1$ day $\mathrm{yr}^{-1}$. We know of no multi-temporal coastal-erosion studies further to the east along the portion of the East Siberian Sea coast with rapid sea-ice change.

The erosion of the low bluffs at Elson Lagoon, Barrow, Alaska, increased from $0.56 \mathrm{~m} \mathrm{yr}^{-1}$ (1948-1979) to $0.86 \mathrm{~m} \mathrm{yr}^{-1}$ (1979-2000) (Brown et al., 2003). Since 1979, we find that the length of the sea-ice-free season has increased by 2 day $\mathrm{yr}^{-1}$ at Barrow and by up to 3.4 day $\mathrm{yr}^{-1}$ just to the west. Further to the east, along the Beaufort Lagoon, the length of the sea-ice-free season has increased 1.52 day $\mathrm{yr}^{-1}$ and coastal erosion was constant at $0.5 \mathrm{~m} \mathrm{yr}^{-1}$ over two time periods (1948-1978, 1978-2001) with substantial variability due to permafrost characteristics (Jorgenson et al., 2002).

At Herschel Island, just to the west of the Mackenzie Delta, we find that the open-water season has increased by $1-$ 1.5 day $\mathrm{yr}^{-1}$ and Lantuit and Pollard (2008) found the mean coastal retreat rate decreased over the period 1954-2000. The regions of Herschel Island with the highest erosion rates are northwest facing and are exposed to the wind (Lantuit and Pollard, 2008). While the mean rate of coastal erosion declined, the regions of Herschel Island with the highest ice content show an increase in thaw-slump activity and an increase in the coastal retreat rate (Lantuit and Pollard, 2008).

Along the Canadian Beaufort Sea in the Mackenzie Delta region, the open-water season has expanded around 1 day $\mathrm{yr}^{-1}$. Mackenzie River total annual discharge has not increased over 1964-2011 (Lesack et al., 2013). However, while there is no observed change in the date of freshet initiation, the duration between freshet initiation peak flow has shortened, and breakup in the Mackenzie Delta is occurring earlier (Lesack et al., 2013, 2014).

Similar to Herschel Island to the west, in this region, the coastal dynamics are characterized by retreat of the shoreline, but do not show an increase in rates through time (measurements made between 1972-2000 Solomon, 2005). The highest rates are along coastlines exposed to winds from the northwest, which set water up, and the lowest rates are in areas sheltered from the wind (Solomon, 2005). There is significant spatial variability within and between coastal zones, associated with variations in geomorphology and lithology (Solomon, 2005).

In the Canadian Arctic Archipelago, the coasts are rocky and the sea-ice cover change is variable. At Resolute Bay, a gravel beach, progradation dominated over erosion throughout the period 1958-2006 due to a combination of 


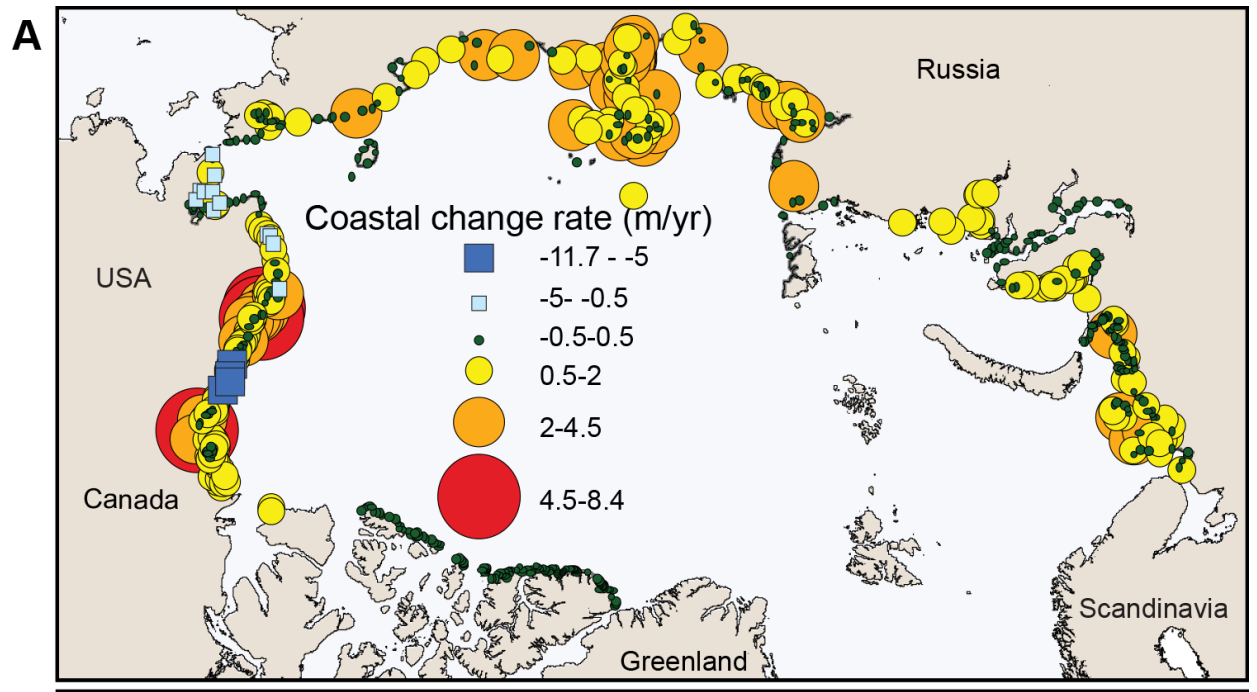

B

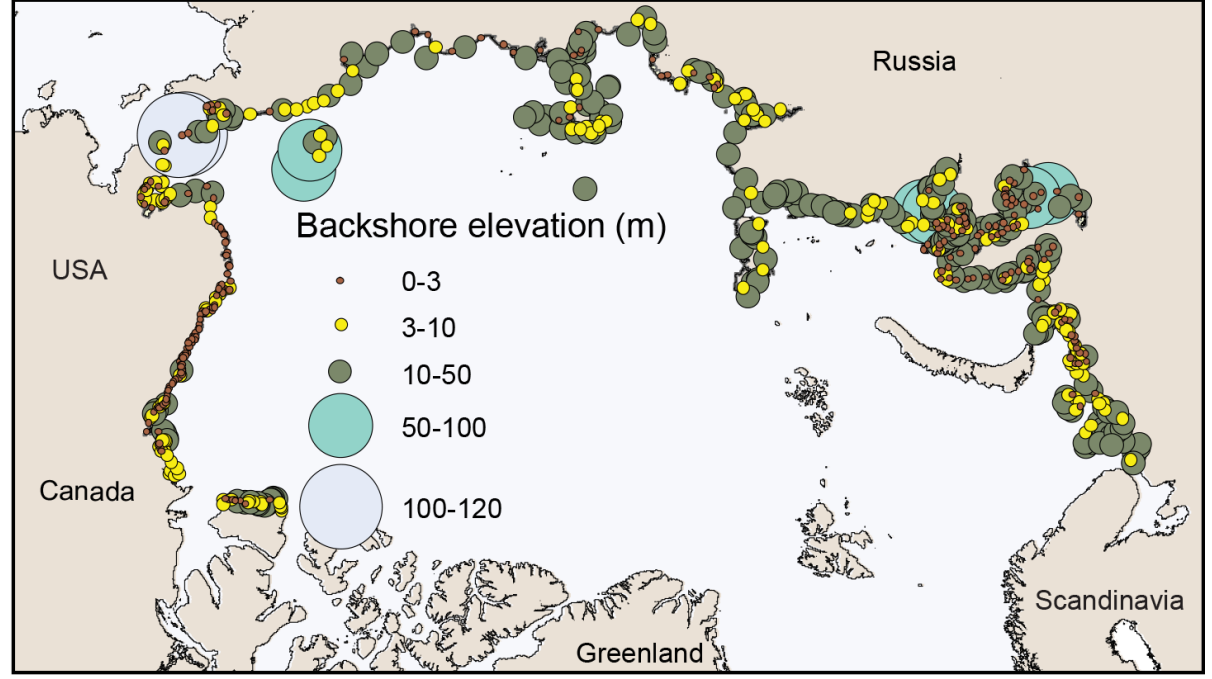

C

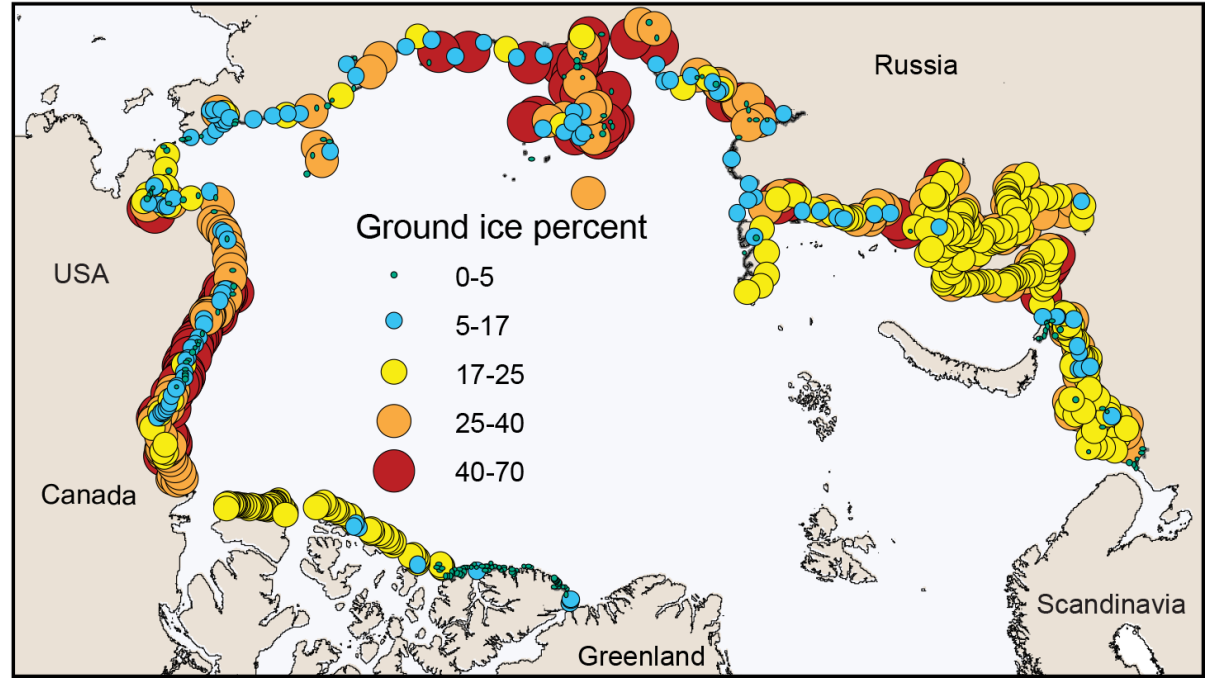

Figure 5. Whole-Arctic coastal erosion and deposition (a), backshore elevation (b), and ground-ice content (c) from the Arctic Coastal Dynamics database (Lantuit et al., 2012). A total of $49 \%$ of the segments have erosion rates below $1 \mathrm{~m} \mathrm{yr}^{-1}$ and $40 \%$ of the segments have rates below $2 \mathrm{~m} \mathrm{yr}^{-1}$. Deposition along the Beaufort Sea occurs in deltaic regions from the Colville River east and along coastal barriers, spits, and forelands west of the Mackenzie River delta. The backshore elevation provides control on the vulnerability of a coast to inundation. Areas with high ice content can experience rapid erosion and are susceptible to changes in the nearshore water temperature. 


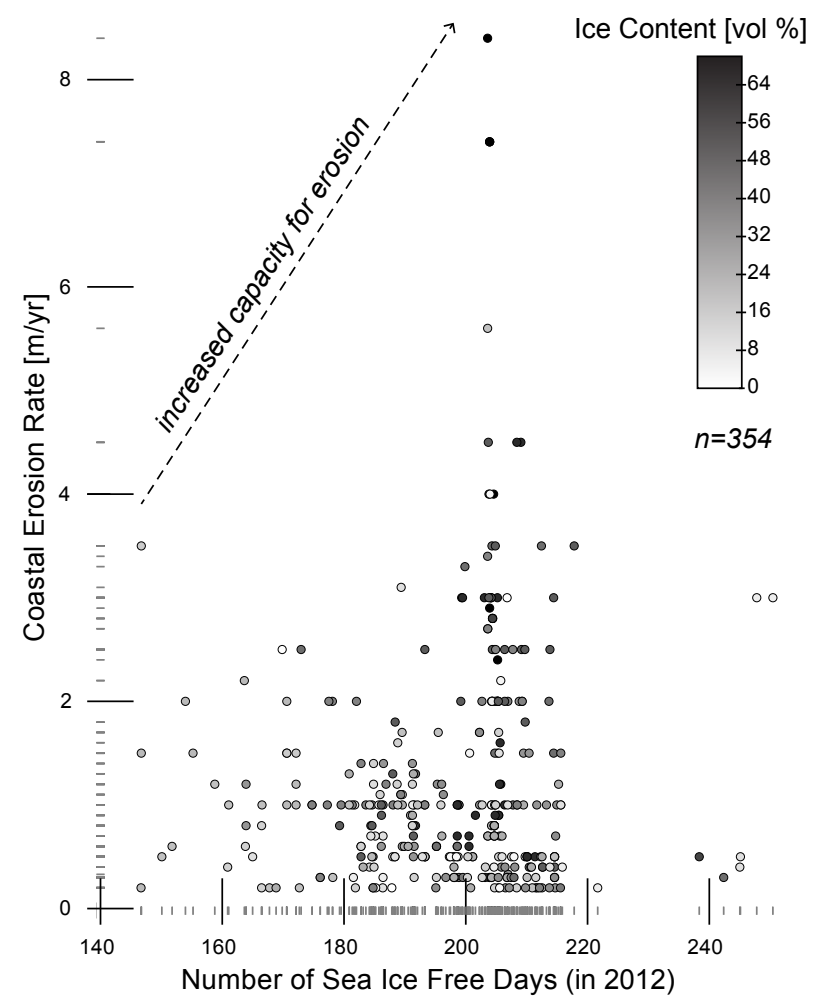

Figure 6. Comparison of coastal-erosion rate and ice content from the Arctic Coastal Dynamics database (Lantuit et al., 2012) and the number of open-water days for 2012 (same analysis as in Fig. 1). For visual clarity, only points with erosion rates greater than $0.1 \mathrm{~m} \mathrm{yr}^{-1}$ are plotted. Gray tick marks on $x$ and $y$ axes indicate the distribution of values. The relationship between open-water days, erosion rate, and ice content is not simple. Up until $\sim 220$ openwater days, the longer the open-water season, and the higher the ice content, the greater the capacity for high coastal-erosion rates.

post-glacial rebound-related emergence and sediment supply (St-Hilaire-Gravel et al., 2012). In the northern portion of the Canadian Arctic Archipelago, the open-water season has not changed, but in Resolute Bay, it has increased by just under 1 day $\mathrm{yr}^{-1}$. In this region, further increases in the duration of open-water conditions will likely not result in rapid increases in erosion due to the resistant nature of the terrestrial lithology. Emergence also serves to create land.

In Svalbard, there is little ice-rich permafrost and seaice change is spatially variable. Along the northern portion of the archipelago, the open-water season has expanded by up to 3.3 day $\mathrm{yr}^{-1}$, while rates of expansion are lower in the southeast and are not significant in the southwest. Three sites in unconsolidated sediments in central Spitsbergen near Longyearbyen give low erosion rates $\left(<1 \mathrm{~m} \mathrm{yr}^{-1}\right)$ and have decelerated over the period 1977-2003 associated with the progradation of a delta (Sessford, 2013). Sites further south, near Recherchefjorden, show net erosion but no clear temporal trends (Zagórski, 2011).
These studies highlight the complicated relationship between changes in the sea-ice season and changes in coastalerosion rates. The length of the open-water season has increased along all of the preceding coastlines, yet only one of the studied regions shows an increase in coastal-erosion rates through time: the sites in the eastern Laptev Sea studied by Günther et al. (2013). All other regions show a large amount of spatial variability due to storm climate, the underlying lithology, and local geomorphology.

Our analysis indicates that the length of the open-water season has increased in all of these locations by varying amounts. Many of the presented sites have rapid rates of erosion. However, averaging coastal-erosion rates over areas with variable geomorphology, lithology, and ice content may mask the relationship between sea-ice change and changing coastal-erosion rates. It is also challenging to compare rates measured over different length intervals due to the potential for non-stationarity in erosion rates (e.g., Sadler, 1981). If a signal exists in the relationship between changing sea ice and changing coastal erosion, we are most likely to see it in rapidly eroding regions. It is worth considering the smallest stretch of coastline for which one can make a significant link between geomorphic rates and changing environment. At Drew Point, most of the coastal-erosion rates are determined for a $70 \mathrm{~km}$ long coastal segment.

We have focused on the relationship between length of open water and coastal erosion. While sea ice provides firstorder constraints, variability of other changes, such as atmospheric warming and storm tracks, may play a significant role.

\subsection{Drew Point}

While we are able to examine the impact of the duration of open water on coastal erosion at well-studied sites, it is the passage of storms that does the geomorphic work. At Drew Point, we have a rich record of coastal-erosion and environmental observations. At this location, we can trace the dependence of the processes and rates of coastal evolution first to the nearshore conditions, and then determine the dependence of nearshore conditions on sea ice.

Our analysis of coastal exposure at Drew Point can serve as a template for analyzing the impact of changing sea ice on other Arctic coasts. Satellite-derived daily or every-otherday sea-ice concentrations are available for the whole Arctic, starting in 1979. This data set documents changes in the length and nature of the open-water season, which provides the first-order control on Arctic coastal impacts. However, a full understanding of how changing sea ice will impact coasts depends on both the form and substrate of the coast and the way in which sea ice influences the nearshore conditions in a particular area. While the erosion processes, operative at Drew Point, are not universally applicable to all Arctic coasts, the link between coastal dynamics and sea ice 


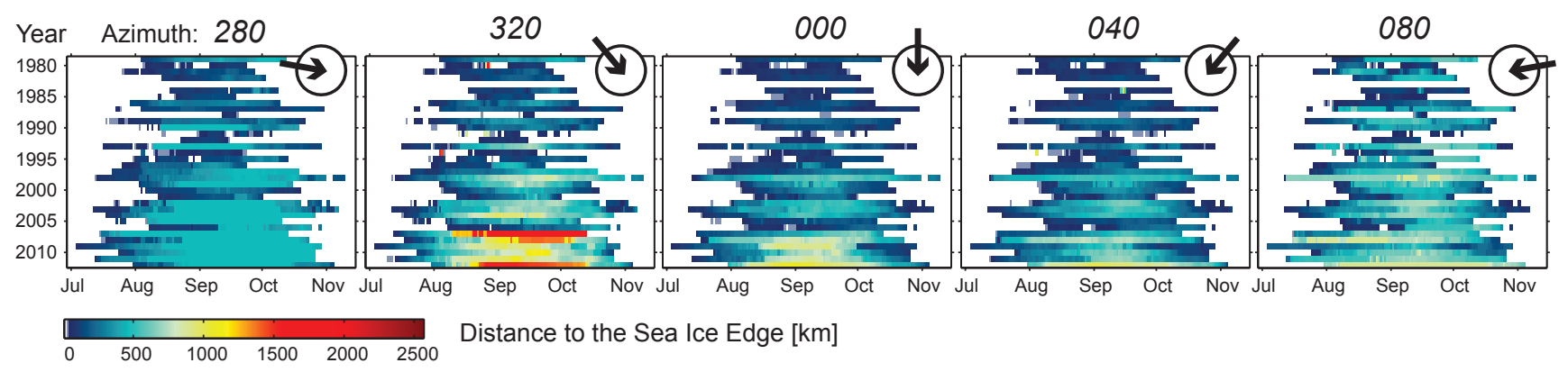

Figure 7. Distance to the sea-ice edge from Drew Point for the period 1979-2012. Both the length of the open-water season and the distance to the sea-ice edge have increased in this time period. The distance to the sea-ice edge has increased the most in the northwest direction, which is the direction from which wind blowing sets up nearshore water levels.

through the nearshore conditions exists along all ice-affected coasts.

We first focus on the distance to the sea-ice edge and then construct a coastal-exposure history.

\subsubsection{Fetch at Drew Point}

At Drew Point, not only has the duration of the open-water season increased substantially since the beginning of satellite observations (Overeem et al., 2011), but the distance to the sea-ice edge has increased as well. The direction from which wind blows influences whether the water level at the coast is set up or set down (Fig. 4). At Drew Point, erosion is most effective when the water level is set up (Barnhart et al., 2014), and thus it is critical to evaluate the spatial component of changes in the distance to the sea-ice edge.

We calculate the distance to the sea-ice edge at Drew Point (SIC $=15 \%$ ) for all ocean azimuths at $10^{\circ}$ increments (see method outlined in Overeem et al., 2011 and applied by Barnhart et al., 2014). Figure 7 illustrates the results from five azimuths $(280,320,000,040$, and 080) and shows the increase in the length of the open-water season, the interannual variability in the length, and the distance to the sea-ice edge. The increase in distance to the sea-ice edge is particularly pronounced for winds from the west (azimuth 320), the direction from which wind sets up water levels in this region.

These observations motivate asking how the change in fetch is related to the increase in the duration of the openwater season. We compare the maximum fetch in each azimuth bin for each year with the duration of the open-water season (Fig. 8). The maximum distance to the sea-ice edge has increased through time, more dramatically in the west than in the east (Fig. 8a and b). The evolution of the openwater season in this area explains this pattern; open water typically develops from the Bering Strait to the east and from the Canadian Beaufort Sea to the west. By the time it reaches Drew Point, open water extends from Drew Point to the Bering Strait. The length of the open-water season and the maximum fetch are therefore positively related (Fig. 8c and d), with the largest maximum fetches associated with the longest open-water seasons. For 6 of the years, the maximum fetch to the northwest (azimuth 320) is large (>1400 km) with no relationship to the duration of open-water conditions (Fig. 8, orange dots). These are years of extensive open water in the northern Laptev Sea.

\subsection{Water exposure history}

The increase in open water and fetch provides increased potential for coastal change, but the coast will feel the impact only if a storm passes by. The fetch analysis (Sect. 5.2.1) documents how the open-water season has changed at Drew Point, but it does not include nearshore water-level and wave conditions. We therefore construct a model of storm surges and waves to reconstruct the water exposure history and test it against observations from Drew Point. The relationship between the wind field and observed changes in the water level and wave height (Fig. 4) suggests that the nearshore water level can be modeled with a simple bathystrophic stormsurge model.

We calculate the "directional fetch", or distance to sea-ice edge in the direction from which the wind is blowing (Fig. 9), which serves as a metric for the potential impact of the seaice retreat on the coast. The directional fetch and the wind field are used as inputs to this model of storm surge and wave height. In this section, we first outline the construction of this model (full details are available in the Supplement to Barnhart et al., 2014), apply this model in a theoretical sense to investigate the role of increasing fetch on changes to the nearshore environment, and then calculate the exposure to water-level setup and wave field for the period 1979-2012 at Drew Point.

\subsubsection{Sea-ice control on waves and storm surges}

Sea ice reduces the magnitude of waves and storm surges. The details of wave-sea-ice interactions is an area of current research and most of this research focuses on propagation of waves into, rather than out of, the sea-ice pack (e.g., Asplin et al., 2012). It is, however, understood that surface waves 

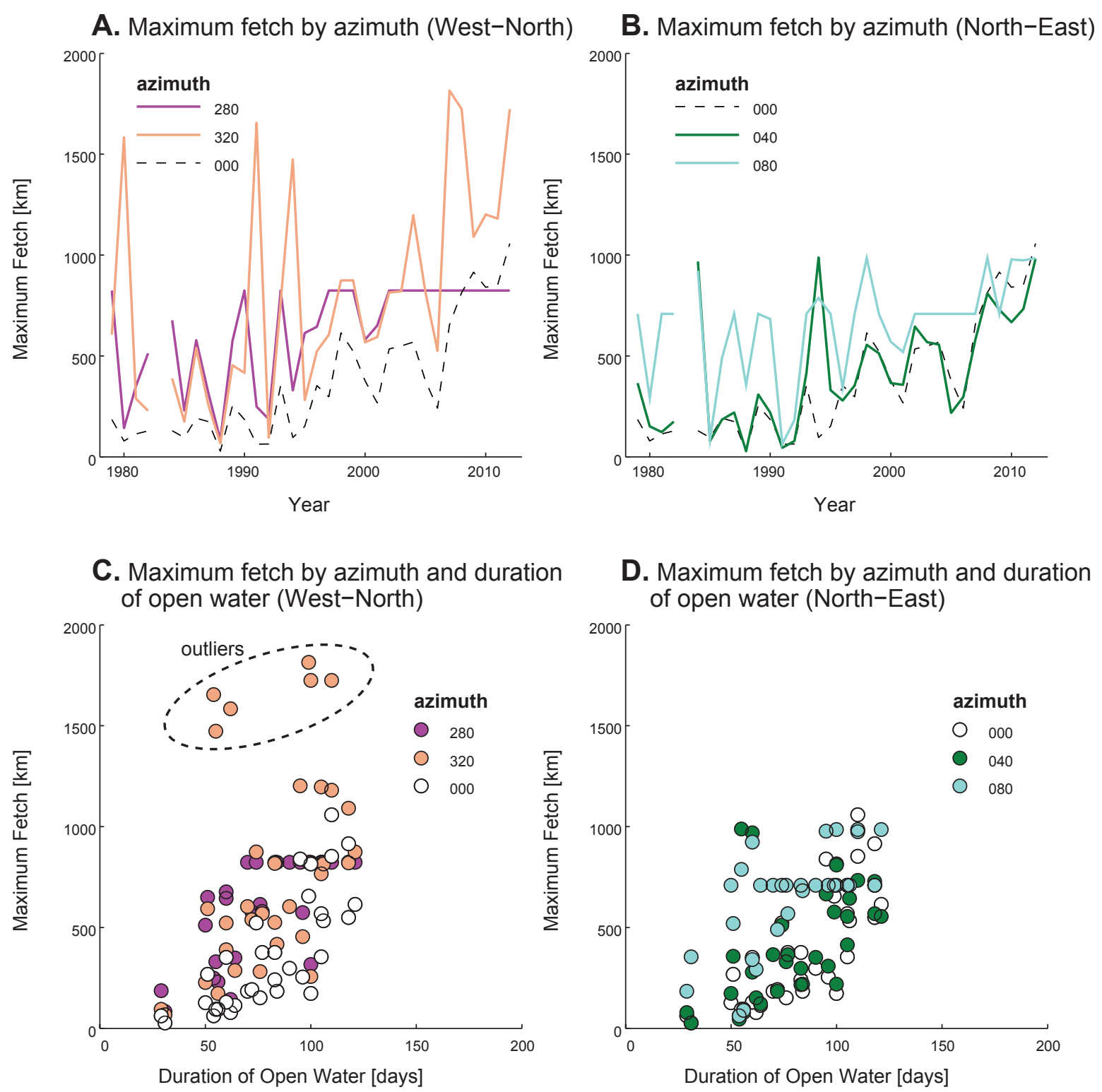

Figure 8. Maximum distance to the sea-ice edge (fetch) as a function of azimuth and time for west (a) and east (b) azimuths and a function of azimuth and duration ( $\mathbf{c}$ and $\mathbf{d}$ ). The maximum fetch has increased over the observation period and is typically greater in the west than in the east. The fetch to the west (azimuth 270) reaches a maximum at just under $800 \mathrm{~km}$ when it reaches Wrangel Island in the Chukchi Sea. There is a positive relationship between the length of the open-water season and the maximum fetch (c and d). The maximum fetch to the northwest (azimuth 330) has the least well-defined relationship with duration of open-water conditions (c, light purple dots). This is a direction from which wind sets water levels up at the coast (Fig. 4a).

are attenuated in sea ice (Wadhams et al., 1988; Squire, 2007). Lisitzin (1974) argued that sea ice will reduce the generation of storm surges. Although the wind stress at the atmosphere-ice boundary may be comparable to that at the atmosphere-ocean boundary, the drag coefficient will differ and the wind stress acting on the sea ice will not pile up water to create a storm surge. More recent research finds that the air-sea-ice drag coefficient reaches a maximum at $50 \%$ ice coverage and decreases with both increasing and decreasing ice coverage (Birnbaum and Lüpkes, 2002; Garbrecht et al., 2002). Observations by Lisitzin (1974) in the Baltic Sea and Henry (1975) in the Beaufort Sea reveal that storm-surge amplitudes were smaller when sea ice was present. Other observations are inconclusive (Murty and Polavarapu, 1979).

Storm surge models that incorporate sea ice to some extent have been developed and applied to the Beaufort Sea region. However, like wave-sea-ice interactions, fully incorporating sea ice into storm-surge modeling is still an area of active 

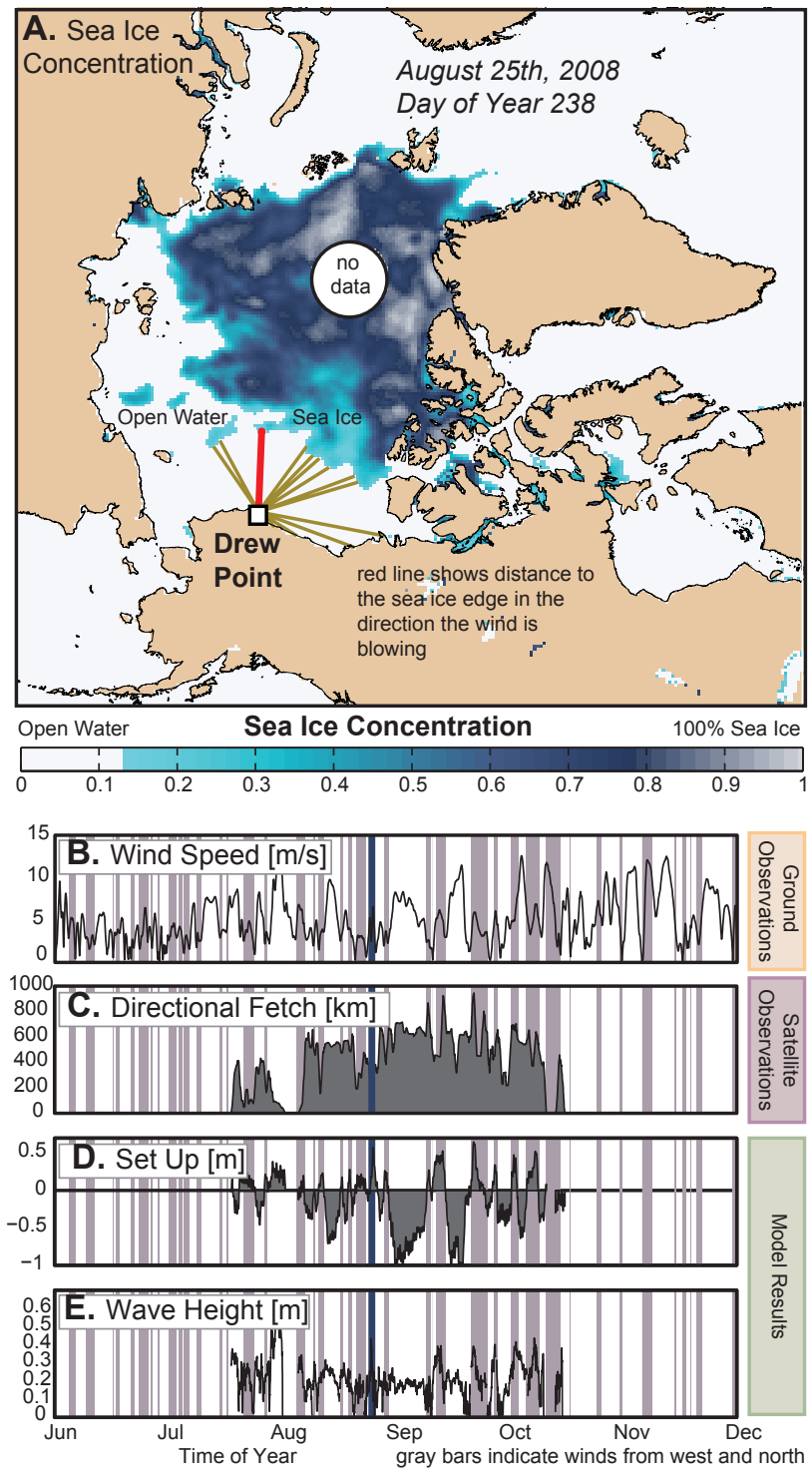

Figure 9. The "directional fetch" is the distance to the sea-ice edge in the direction from which the wind is blowing. The directional fetch is constructed using the hourly wind field from Barrow, adjusted for Drew Point, and the daily location of the sea-ice edge. The upper panel shows sea-ice concentration on 25 August 2008, with distance to the sea-ice edge in the direction from which the wind is blowing at that time (red line) and other azimuths (yellow lines). The directional fetch is used as the maximum distance over which water can be set up or set down and waves can be generated. Based on the wind speed, wind direction, and directional fetch, the setup and set down are calculated (lower panel).

research. Kowalik (1984) and Danard et al. (1989) applied a full hydrodynamic model using sea-ice observations from Canadian Ice Service charts. Two more recent studies are inconclusive about the role of sea ice in storm-surge generation, primarily because sea ice is not well incorporated into existing storm-surge models (Manson and Solomon, 2007; Lynch et al., 2008). Lintern et al. (2011) used the sea-ice edge to set the area over which wind and water could interact in Delft3D model runs and found that changing the distance to the sea-ice edge significantly impacted the development of the wave field. We use a similar approach and set the directional fetch as the maximum distance over which wave and setup can generate. Although it does not acknowledge wave generation and propagation through sea ice, it produced reasonable results.

\subsubsection{Storm surge and wave model}

We find that we can successfully model wind-driven setup and wave generation using the storm-surge and wave model developed for Drew Point by Barnhart et al. (2014). The model combines the bathystrophic storm-surge model of Dean and Dalrymple (1991) (Sect. 5.9.1), including the effect of wave setup outlined by Dean and Dalrymple (2004) (Sect. 5.2.6), and using the fetch-limited wave model of Coastal Engineering Research Center (1984) (Equations 339 and 3-40). We incorporate sea ice only by using the distance to the sea-ice edge as the fetch for storm-surge and wave generation, as discussed above. Our treatment of the hydrodynamics is less sophisticated than that of prior researchers, although considering the simple coastal geometry and bathymetry at Drew Point, we think this approach is justified.

This model calculates the water-level setup or set down and wave height as a function of the $10 \mathrm{~m}$ wind speed, wind direction, fetch, and bathymetry. At each time step, the model determines fetch in a straight line from the sea-ice edge to the shore in the direction from which wind is blowing. It then calculates the setup and wave height along the wind path. If the wave height exceeds a critical fraction of the water depth, the model includes the influence of wave setup (see Supplement of Barnhart et al., 2014, for a full explanation of the model).

Fetch is spatially and temporally variable due to the changing wind field, the geometry of the shoreline, and the temporally variable location of the sea-ice edge. Based on the geometry of the shoreline near Drew Point, we use a fetch of $1 \mathrm{~km}$ for winds blowing offshore (from azimuths ranging from 085 to $200^{\circ}$ ), we limit the fetch to a maximum of $15 \mathrm{~km}$ for winds blowing from the direction of the interior of Smith Bay $\left(200\right.$ to $\left.260^{\circ}\right)$, and we use the distance to the sea-ice edge for all other azimuths. These parameters optimize the correlation between observed and predicted water-level and wave-field characteristics over the summer 2009 field season during which we documented water level.

We recognize that, in reality, the wind field will not be constant from the sea-ice edge to the coastline, and that our treatment simplifies the geometry of the storm-surge problem and neglects many wave processes not present in the Coastal Engineering Research Center wave model. Likewise, the wind 

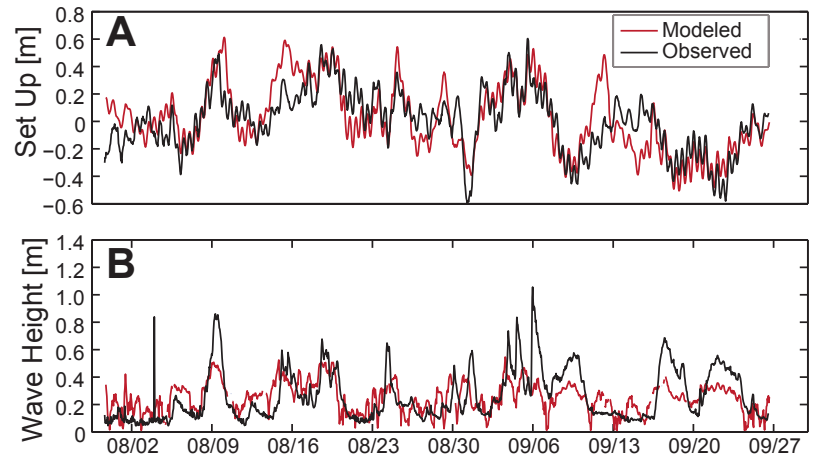
Date, 20.09
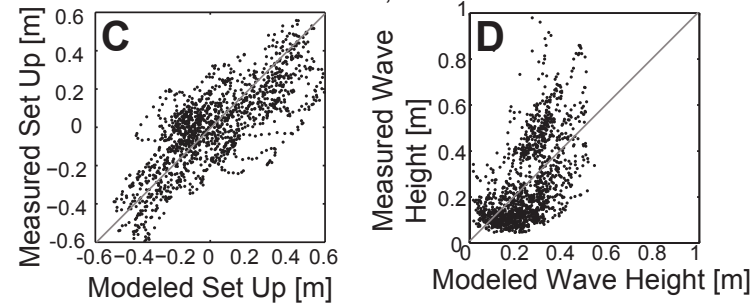

Figure 10. Measured and modeled setup and wave height for summer 2009. Buoy was deployed in $2.2 \mathrm{~m}$ water depth.

field measured on land likely differs from the open-ocean wind conditions. We compare the model with observations collected at Drew Point in 2009 (Fig. 10). Despite all simplifying assumptions, modeled setup and set down agree well with observations made in the summers of 2009 and 2010. For setup, we find a $R^{2}$ of 0.50 and a root mean squared error (RMSE) of 0.15 . For the wave field, we find a $R^{2}$ of 0.37 and a RMSE of 0.14. Visual examination of the time series (Fig. 10a and b) shows that the modeled setup track observations with only a few major departures, and that the modeled wave height does well for all but the highest wave heights, where it under-predicts by $20-40 \mathrm{~cm}$. We therefore consider it reasonable to extend the modeled period to 1979-2012 to examine how the wave field and water level have changed over this period, thus evaluating the role of sea-ice retreat on coastal hydrodynamics.

\subsubsection{Influence of fetch on nearshore conditions}

The increasing extent of summertime open water provides increasing fetch. In entirely open-water conditions, the maximum directional fetch for any azimuth will be set by the geometry of the Arctic coastline. In these conditions, the location, path, and geometry of the storm systems sets limits on the fetch over, which setup and waves can form. We ask what limits on the maximum fetch exist in this system? In the absence of nearshore sea ice, is there a distance that is less than the size of a synoptic scale storm $(\sim 1000 \mathrm{~km})$ at which setup or wave height "saturate" and no longer continue to increase with increasing fetch?
We use the storm-surge and wave model to explore how changing fetch from 0 to $1000 \mathrm{~km}$ affects the nearshore conditions for wind from all offshore directions and for wind speeds that vary from 1 to $18 \mathrm{~m} \mathrm{~s}^{-1}$. Figure 11 shows results from three wind directions: 280, 000, and 080. This experiment is conducted for a coast with the same geometry as Drew Point in $1 \mathrm{~m}$ water depth.

We find that when winds are from the west, increasing fetch and increasing wind speed both result in increased setup and wave heights (Fig. 11, leftmost column). These conditions produce the highest positive setup values. Wind from the north sets water up, but less so than wind from the west (Fig. 11, center column), whereas wind from the east sets water levels down (Fig. 11, right column). We present both the wave heights calculated for water depth dynamically adjusted by the wind-driven setup (Fig. 11b) and for wave heights in a constant water depth (Fig. 11c). The wave heights calculated dynamically are more physically reasonable, have directional dependence, and can reach higher values due to the increased water depth associated with setup.

In the most realistic model, in which we have dynamic coupling between the setup of water level and waves (Fig. 11b), we do not find a fetch beyond which the setup or wave height "saturate" and no longer continue to increase with increasing fetch. Thus, the larger the fetch, the larger the storm-surge and wave heights. This contrasts with a noncoupled wave model in which the fetch-limited wave model saturates at about 100-200 km (Fig. 11c), and, as expected, argues for this coupling in such models.

\subsubsection{Coastal-exposure history}

We calculate yearly averaged values of environmental conditions and exposure metrics for one offshore pixel at Drew Point for the period 1979-2012 (Fig. 12, cell [208, 226] in the $304 \times 448$ Northern Hemisphere grid). The coast is vulnerable when water levels are set up, thus we calculate the number of open-water days each year and the proportion of these with wind from west to north (azimuths between 270 and 010). Larger fetches can result in larger setup, so we determine the distribution of fetch when wind is from the west. Using our storm-surge and wave-model output, we calculate three metrics of coastal exposure in the nearshore based on the accumulated (1) "positive setup", (2) duration of positive setup, and (3) wave height over each open-water season.

The duration of the open-water season and the duration of time that wind is from the west show significant positive trends (Fig. 12a). Not only is the duration of time that the wind is from the west increasing, but the mean, 10th, and 90th percentiles of the directional fetch when the wind is from the west and north (the directions that result in water-level setup) have increased. We have not fit a trend to Fig. 12b. Figure 12a and b represent a convolution of the changes in fetch shown in Fig. 7 and the wind field. 


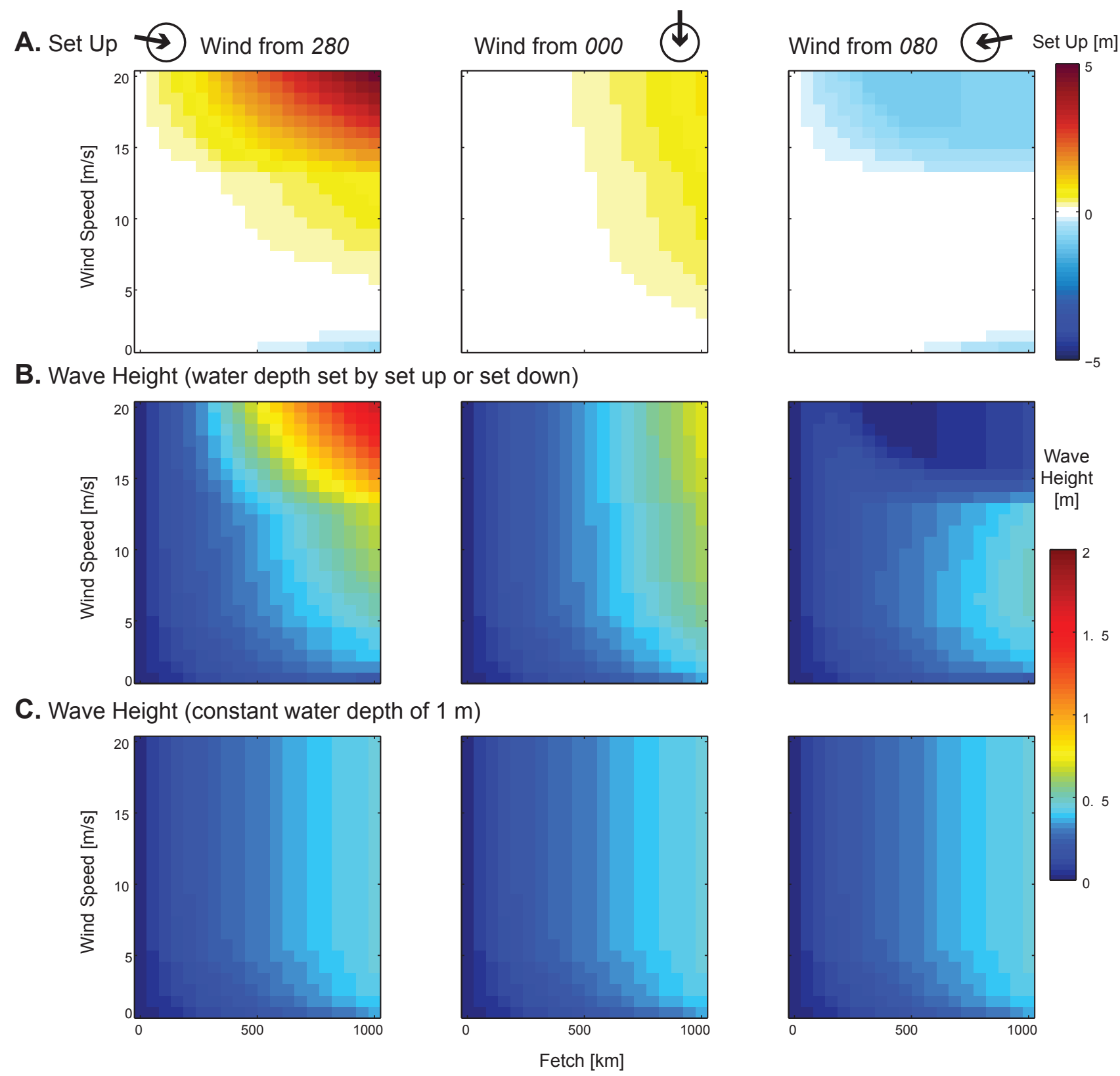

Figure 11. Theoretical setup in $1 \mathrm{~m}$ mean water depth (a), wave height calculated in water depth modulated by set up (b), and wave height (c) with a constant water depth at $1 \mathrm{~m}$ for an east-west oriented coastal shelf. Wind from the west and the north sets water levels up while wind from the east sets water down. Neither setup nor wave height saturate at a critical fetch.

In Fig. 12c-e, we show the yearly and cumulative value for each exposure metric, as well as the slope and $95 \%$ confidence bounds, $R^{2}$, and RMSE of a linear trend line fit to the yearly values. The positive set has units of meters per day and represents the sum of all the setup that is greater than zero over each summer open-water season. The duration of positive setup is the amount of time in each open-water season that the setup is positive. The wave-height metric is similar to the positive setup in that it represents the sum of all of the wave heights over the open-water season.
All three exposure metrics show significant positive trends and significant inter-annual variability (Fig. 12c-e) which may be due to increases in the magnitude and duration of setup and wave height, or the increased duration of openwater conditions. We analyzed each exposure metric normalized by the length of open water for each year and found that the normalized positive setup is the only metric that shows a significant positive trend. Thus, the primary factor that influences these exposure metrics is the length of the openwater season. 


\section{Environmental Conditions}

A. Sea Ice Free Conditions

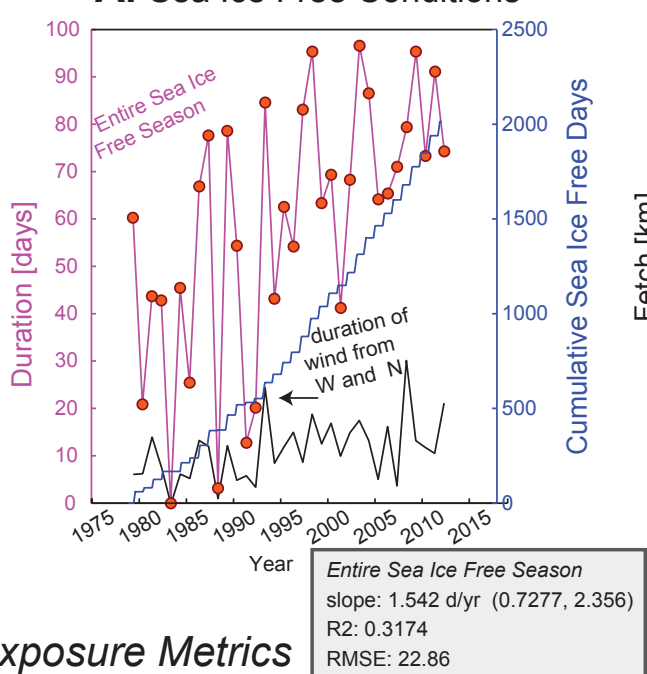

B. Directional Fetch When Wind is From West and North

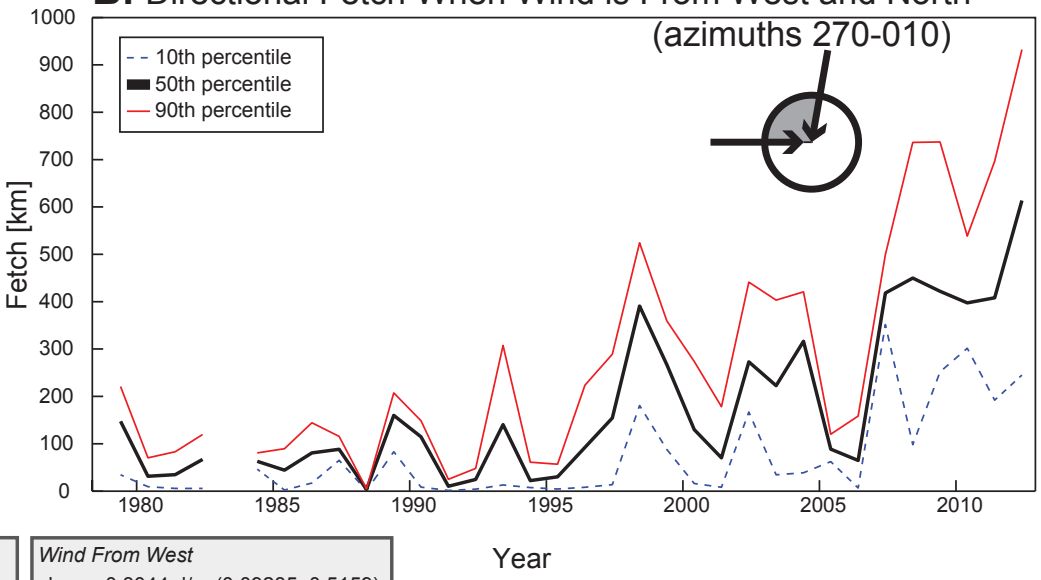

slope: $0.3044 \mathrm{~d} / \mathrm{yr}(0.09285,0.5159)$ R2: 0.2117 RMSE: 5.94
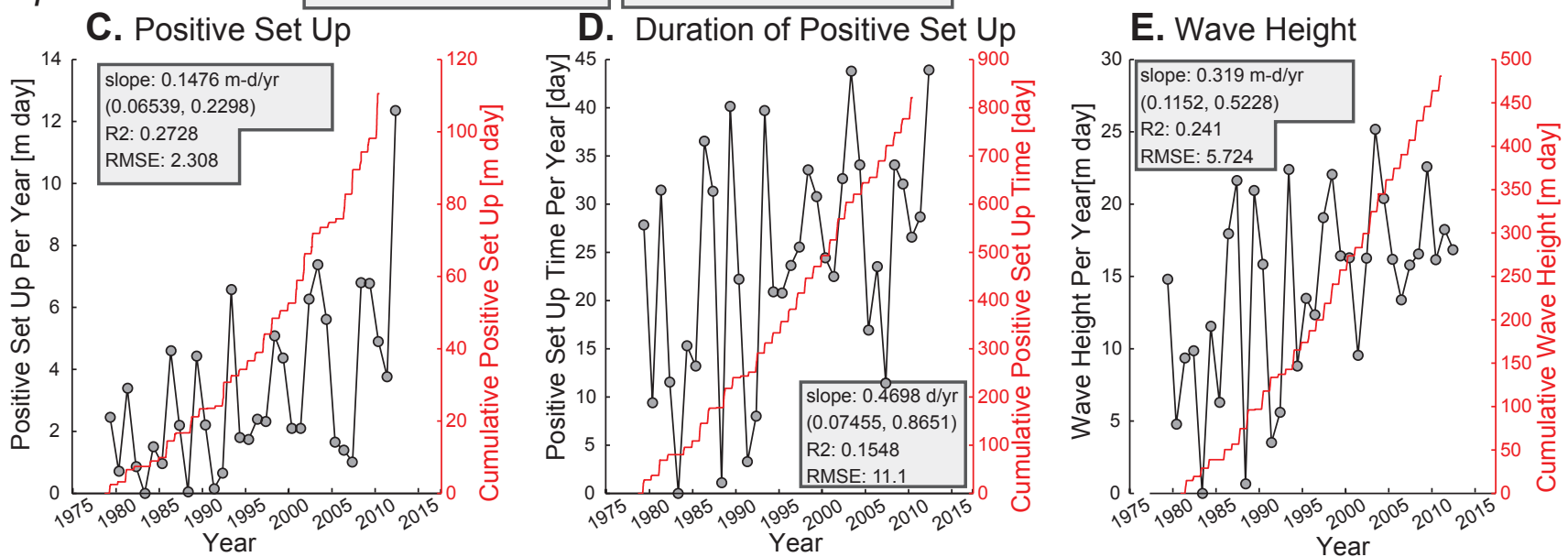

Figure 12. Environmental conditions (top row), exposure metrics (middle row), and normalized exposure metrics (bottom row) calculated at Drew Point over the period 1979-2012. In (a) and (c)-(e), we show both the value for the yearly metric (left-hand axis) and the cumulative value (right-hand axis). The duration of the open-water season and the duration of winds from the west both show a significant increase over this time period (a). The slope of a linear trend line (with $95 \%$ confidence bounds in parentheses), the $R^{2}$, and RMSE are given for each yearly metric in the boxes, gray indicates significant at $95 \%$ level and white indicates not significant. The distance to the sea-ice edge (directional fetch) when the wind is from the west has increased (b). The three exposure metrics - positive setup (c), duration of positive setup (d), and wave height (e) - all show large inter-annual variability and all have significant positive linear trends.

We calculate one additional measure of the nearshore environment: the distribution of the directional fetch and positive setup (Fig. 13). We find the 5th, 25th, 50th, 75th, and 95th percentile values for each variable (the 95th percentile value represent the value for which $5 \%$ of values are above and $95 \%$ are below). The distribution of directional fetch (Fig. 13a) and directional fetch at times of positive setup (Fig. 13b) are similar and increase over the observation period (1979-2012). While the mean values of the positive setup (Fig. 12c) have not increased over the observation period, the extreme values of positive setup did increase over this time period. The distribution of wave heights over the model time period does not show a trend.

\subsubsection{Storm-event analysis}

Along this stretch of coast, most geomorphic work is done during storm events that set up water. We calculate the number of storms per year, the maximum setup or set down, and wave height for all storms over the 1979-2012 period (here, we define a storm as continuous time periods with wind speeds of $\geq 10 \mathrm{~m} \mathrm{~s}^{-1}$, as employed by Atkinson, 2005). For this period, we also find the number of positive setup events - defined as events in which the water level was set up 
A. Distribution of directional fetch (dF)

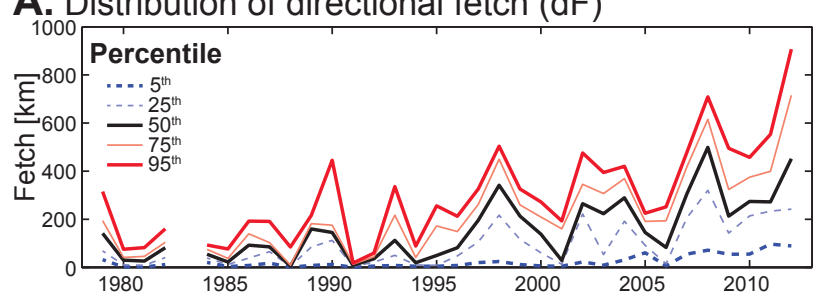

B. Distribution of $\mathrm{dF}$ for times with positive set up

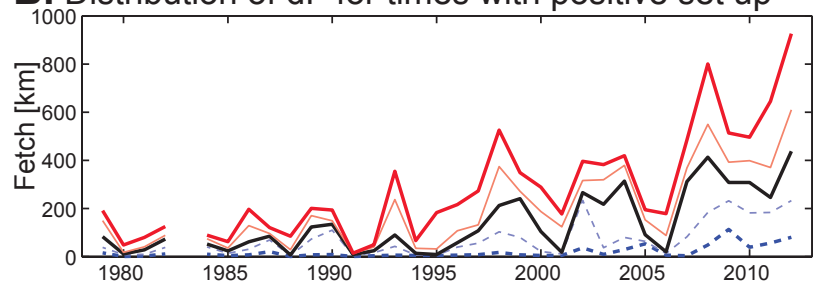

C. Distribution of modeled positive set up

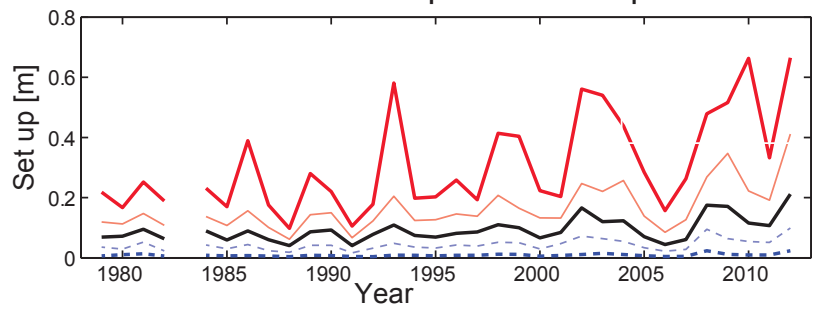

Figure 13. Distribution of directional fetch for each year all open water conditions (a), times when water levels are set up (b), and distribution of modeled positive setup (c). We show the 5th, 25th, 50th, 75 th, and 95 th percentile values for each variable. The 95th percentile values represent the value for which $5 \%$ of values are above and $95 \%$ are below. The distribution of directional fetch (a) and directional fetch when setup is positive (b) are similar and increase over the observation period (1979-2012). While the mean values of the positive setup (Fig. 12c) have not increased over the observation period, the extreme values of positive setup also increase over this time period.

above the base of the coastal bluffs with no regard to the wind speed or direction. For each storm or positive setup event, we extract the highest water-level setup or set down and wave height (Fig. 14), and the wind direction and directional fetch at the time of peak wind speed (Fig. 15).

Over the 1979-2012 period, we find 799 storms, only 28 of which set water levels up. Over this same time, we find 306 positive setup events. The number of storms per year has not changed through time, and the number of storms that set up water make up a small proportion of the total number of storms (Fig. 14a). This observation mirrors field observations at Drew Point (Wobus et al., 2011; Barnhart et al., 2014), which indicate that small storms can still bring enough setup to lap water at the base of the coastal bluffs and accomplish substantial geomorphic work.

The discrepancy between 28 positive setup storms, and 306 positive setup events reveals that there are many pos- itive setup events that are not captured in the latter category, though the wind-based definition of a storm captures most of the highest values. The number of positive setup events is increasing (95\% confidence bounds on slope: [0.12, 0.62 ] events per year; $R^{2}=0.25$, RMSE $=6.68$ ). Normalizing by the length of the open-water season still yields a weak but positive trend (95\% confidence bounds on slope: [0.03, $0.22]$ events per month of open water per year; $R^{2}=0.16$, RMSE $=0.09$ ). The magnitude of setup events is similar to that of set-down events (Fig. 14b), while the wave height during setup events tends to be larger than during set-down events (Fig. 14c).

Both storms that set up water and positive setup events have peak wind speeds from the west and north (Fig. 15a). The directional fetch during storms that set down water and for positive setup events has increased through time, whereas the directional fetch during storms that set up water does not exhibit a trend in time (Fig. 15b). High values of extreme positive setup and extreme wave height occur when directional fetch is large, which is consistent with our hypothesis that the distance to the sea-ice edge controls nearshore conditions through the fetch (Fig. 11).

We can compare this storm analysis to the historical record of storms presented in Lynch et al. (2008), who report observations of historical storms at Barrow, AK (five with flooding, eight without over the period 1979-2003). Our analysis is based at Drew Point, which experiences a wind field and storm climate similar to that at Barrow. We find that, of the five storms with flooding, we would predict flooding in three of the cases. We correctly predict no flooding for the other eight wind events.

\section{Discussion}

In the prior section, we present two analyses of the impact of sea-ice change on Arctic coasts. Here, we discuss the changes in coastal exposure at Drew Point and consider the future of Arctic coasts.

\subsection{Changes in coastal exposure at Drew Point}

Changes in coastal exposure over the period 1979-2012 are primarily caused by changes in the duration of the openwater season (Fig. 12a) and the increasing positive extremes of setup magnitude (Fig. 13c). Increasing the open-water season provides a longer period of time in which the nearshore water can interact with the coast, and, in the case of Drew Point, results in rapid coastal erosion. The second of these allows for larger waves, and thus more energy to reach the coast.

The distance to the sea-ice edge, particularly in the west, has increased. Although the distance to the sea-ice edge when the wind blows from the west and north has increased substantially over this time period, we find that increases in the 

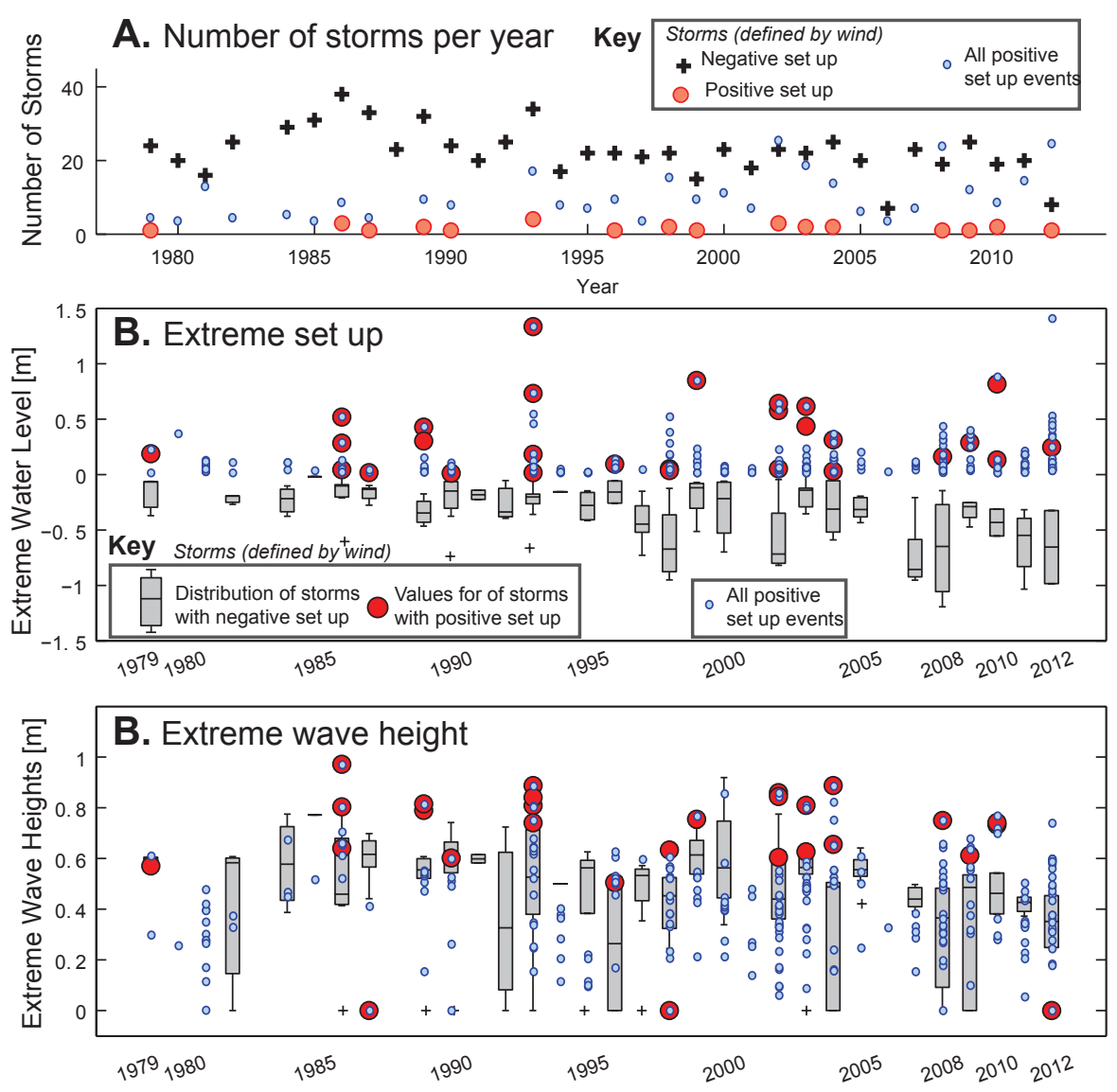

Figure 14. Number of storms per year (a), magnitude of extreme setup or set down (b) and magnitude of extreme wave height (c) for all storms (defined as wind $\geq 10 \mathrm{~m} \mathrm{~s}^{-1}$, red dots and gray bars; we also show "positive setup events", blue dots). Only a small proportion of storms set water up, and the definition of storms based on wind does not capture all positive setup events. There are no clear trends in the number of storms per year, though the number of positive setup events may be increasing.

yearly metrics of coastal exposure at Drew Point can be explained most simply by the increased duration of the openwater season.

Changes in the fetch are not needed to explain the variations in the positive setup, duration of positive setup, or wave-height metrics. However, the fetch has changed over the observation period and is reflected in the increasing extreme values of the positive setup (Fig. 13c). It is hard to disentangle setup, fetch, and duration of the open-water season. A longer open-water season allows more time for storms to pass over open ocean, whereas the directional fetch governs the distance over which storm winds blow, accomplishing either setup or set down. Considering this dependence, it is surprising that we found no trends in the normalized positive setup. However, the number of positive setup events is clearly increasing.

Coastal erosion rates at Drew Point increased from $6.8 \mathrm{~m} \mathrm{yr}^{-1}$ during the period $1955-1979$ to $8.7 \mathrm{~m} \mathrm{yr}^{-1}$ during the period 1979-2002 and $13.6 \mathrm{~m} \mathrm{yr}^{-1}$ for the period 20022007 (Jones et al., 2009). Overeem et al. (2011) found that the increase in erosion rate over the satellite record tracks the average duration of the open-water season. Thus, the increase in open water explains most of the change in the coastalerosion rate. However, the increase in size of large setup events (Fig. 13c) and the increase in frequency of positive setup events (Fig. 14a) likely also contribute to the increased erosion rates observed at Drew Point. The water temperature is another factor for controlling erosion rates in ice-rich permafrost coasts, and is influenced by increasing the duration and the area of open water adjacent to the coast (e.g., Barnhart et al., 2014).

\subsection{Whole-Arctic coastal change and physical vulnerability}

In the context of a future Arctic, in which storminess is predicted to increase, the changes in the duration of open water and fetch distances will likely result in enhanced rates of geomorphic change, inundation, and increased loss of buildings. The geomorphic coastal response to future forcings will depend on both relatively static factors, such as the topography, substrate, and geometry of each segment of coast, 


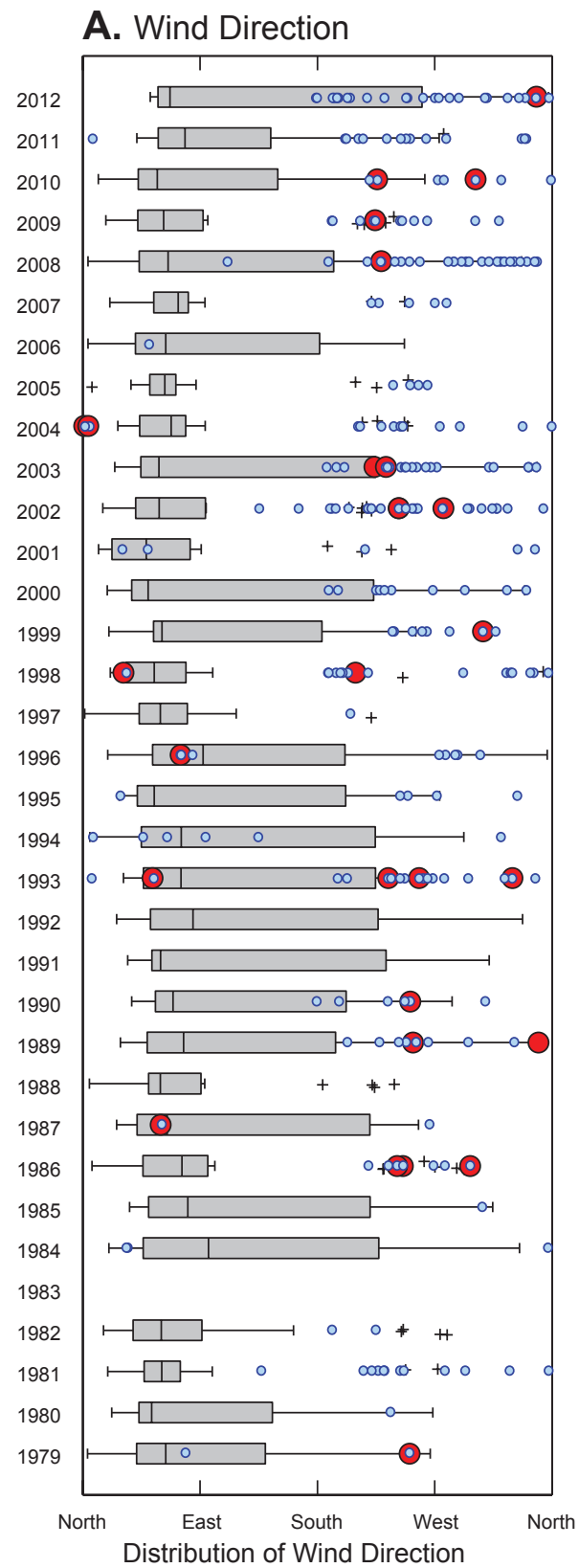

B. Directional Fetch

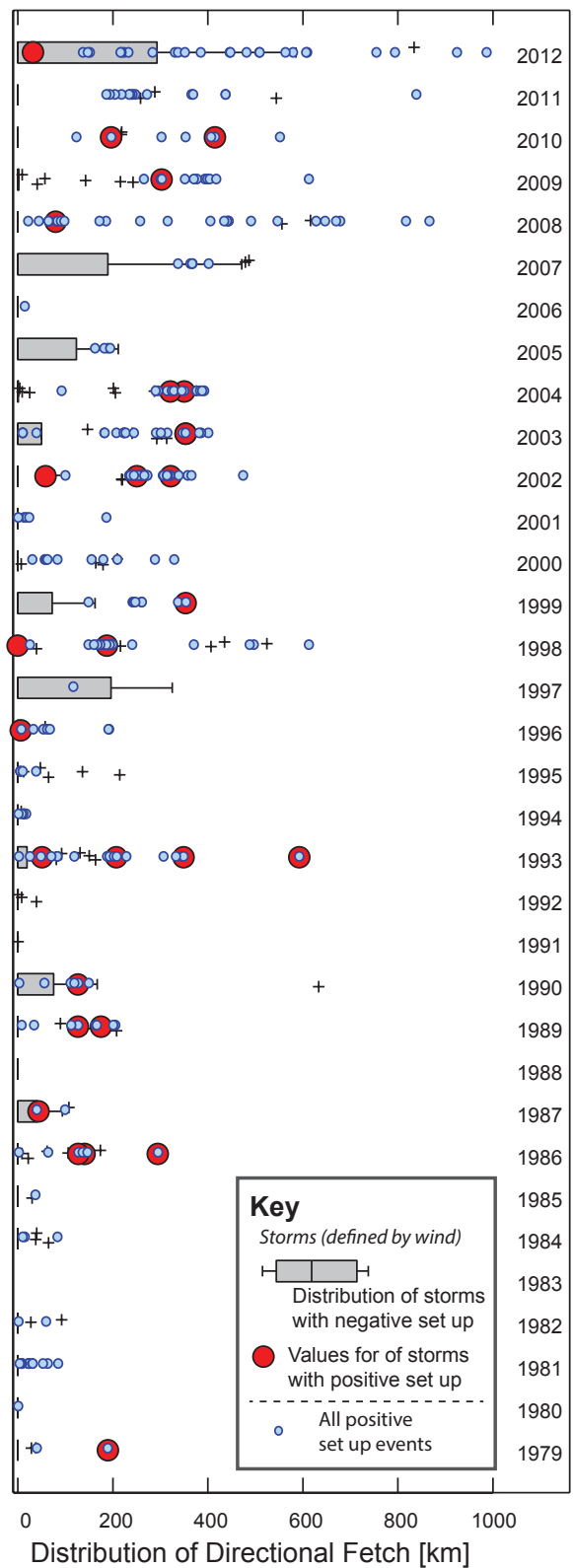

Figure 15. Wind direction (a) and directional fetch (b) by year for all storms (defined as wind $\geq 10 \mathrm{~m} \mathrm{~s}^{-1}$ ) and for positive setup events. Storms that set up water and positive setup events have winds from the west and north. Directional fetch during storms that set down water and positive setup events have increased through time, while directional fetch during storms that set up water does not exhibit this trend.

and dynamic factors, including changes in sea-ice cover, the number and nature of storms, and the associated nearshore water conditions.

Vulnerability to inundation and salinization is enhanced by low backshore elevations and storm-surge sufficient to overtop the beach. Erosion rates are rapid in ice-rich permafrost and also depend on water temperature. Our analysis of the relationship between ice content, average coastal-erosion rate, and length of open-water season (Fig. 6) and of the previ- ously studied sites with multi-temporal coastal-erosion observations. Sect. 5.1.2, however, shows that the details of the coastal-erosion rate are heavily influenced by the local geomorphology and lithology.

As a final step, we consider how the open-water season is expanding in six of the Arctic Sea sectors (Fig. 16). We plot the distribution of the first and last day of the open-water season for each Arctic Sea sector for 1979 and 2012, along with the average daily insolation, and the average monthly 


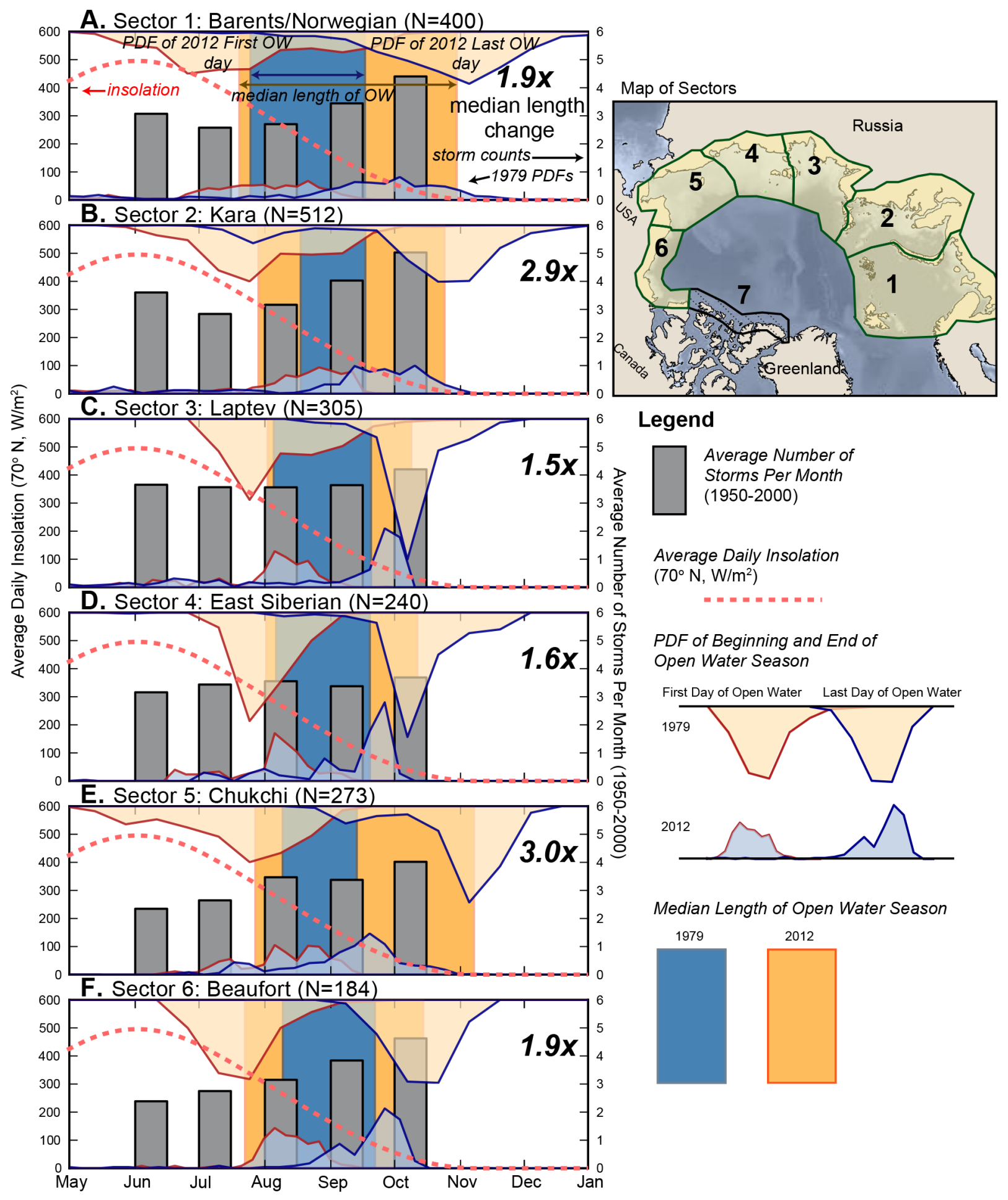

Figure 16. Changes in the length of the open-water season from 1979-2012 by sector (panels on left side). Blue shaded (1979) and yellow shaded (2012) regions show the probability density function of the first day of open water (red outline) and the last day of open water (blue outline). The median length of the open-water season is shown in the figure background. We show the average daily insolation at $70^{\circ}$ north and the average number of storms per month (for the period 1950-2000, from Atkinson, 2005). In many sectors, the fall is stormiest; thus, expansion of the open-water season into the fall allows for additional impact from storms. Expansion of the open-water season into the spring allows for more time at higher insolation levels and thus warmer water temperatures. 
number of storms (from Atkinson, 2005). We do not show the Canadian Arctic (Sector 7) as sea ice persists along the northwestern portion of this segment of coast throughout the summer season. In most sectors, the open-water season has expanded more into the fall than into the spring, as Overeem et al. (2011) found in their analysis at Drew Point.

Strong feedback is enacted by the expansion of the openwater season. While the open-water season in most sectors has roughly doubled in duration since 1979 (the sector averaged factor ranges between 1.5 and 3), it is expanding more into the fall than into the mid-summer (Fig. 16). As the disappearance of the last ice still occurs well after the peak insolation associated with the solstice in mid-June, any expansion earlier into the mid-summer exposes the sea surface to increasingly higher insolation. We should therefore expect higher sea-surface temperatures, which, in turn, drives higher erosion rates on ice-rich coastlines. Expansion of the open-water season into the fall enacts another feedback. As storminess in most sectors increases toward the fall (Fig. 16; Atkinson, 2005), expansion of the open-water season further into the fall exposes the ocean to winds that can drive higher storm surge and higher waves. This should increase the probability that water levels exceed the base of coastal bluffs, enhancing the rate of erosion.

\section{Conclusions}

We have presented a pan-Arctic analysis of satellite-based sea-ice concentration, an analysis of changing spatial patterns and distance to the sea-ice edge at Drew Point, AK, a numerical model that is capable of capturing the nearshore conditions at Drew Point, and an analysis of changing nearshore conditions at Drew Point. This quantifies sea-ice control on Arctic coastal processes, and provides an example application to a highly vulnerable coastline.

We calculate three metrics of the nearshore environment, and find that the factor with the most explanatory power is the duration of the open-water season. Fetch is increasing at Drew Point, particularly toward the west, increasing the size of large setup events. The total number of storms (as defined by wind speed alone) has not changed, and the number of storms with positive setup is small. However, the number of positive setup events (as defined by water level alone) has increased through time. It is at times when water level is set up that erosion occurs in this area (Barnhart et al., 2014).

The duration of open-water conditions along the entire Arctic coastline has roughly doubled in duration since 1979 and is expanding more into the fall than into the mid-summer. The expanding open-water-season results in different feedback in the mid-summer and in the fall. A longer open-water season in the fall provides open water at a time of greater storminess. This will likely result in increased interaction between the coast and the nearshore water, enhancing the rate of erosion. In addition, expansion of open water into the early summer results in warmer surface-water temperatures and higher erosion rates on ice-rich coastlines.

Across the Arctic, at the sites where multi-temporal observations of coastal erosion are available, the relationship between changing open-water conditions and coastal erosion are complicated by lithology, geomorphology, ice content, orientation, storm climate, ice dynamics, relative sea-level trend, and sediment supply, among other factors.

Changing sea-ice-cover results in feedback that increases the rates of coastal erosion. Although, in detail, the vulnerability of a particular reach of coastline will depend on local geomorphology and weather patterns, we should expect coastal-erosion rates to rise most dramatically in areas with rapidly expanding open-water seasons and high ground-ice content.

Acknowledgements. The authors thank D. Atkinson for sharing the storm counts reported in Atkinson (2005) and H. Lantuit for sharing the GIS files for the Arctic Coastal Dynamics database from Lantuit et al. (2012). We kindly thank D. Forbes and an anonymous reviewer for comments that significantly improved the quality and clarity of the manuscript.

This research was funded by ONR-1547946 (Office of Naval Research), ONR-1544301, NSF/OPP-1549620 (National Science Foundation/Office of Polar Programs) to R. S. Anderson, I. Overeem, and Cameron Wobus. K. R. Barnhart is supported by a NASA (National Aeronautics and Space Administration) Earth and Space Science Fellowship (award \#NNX12AN52H), and thanks the Alaska Geological Society for their support.

Edited by: H. Eicken

\section{References}

ACIA: Impacts of a Warming Arctic: Arctic Climate Impact Assessment, Cambridge University Press, Cambridge, UK, 2004.

Asplin, M. G., Galley, R., Barber, D. G., and Prinsenberg, S.: Fracture of summer perennial sea ice by ocean swell as a result of Arctic storms, J. Geophys. Res., 117, C06025, doi:10.1029/2011JC007221, 2012.

Atkinson, D. E.: Observed storminess patterns and trends in the circum-Arctic coastal regime, Geo-Mar. Lett., 25, 98-109, doi:10.1007/s00367-004-0191-0, 2005.

Barnhart, K. R., Anderson, R. S., Overeem, I., Wobus, C., Clow, G. D., and Urban, F.: Modeling erosion of ice-rich permafrost bluffs along the Alaskan Beaufort Sea coast, J. Geophys. Res.-Earth, 119, doi:10.1002/2013JF002845, 2014.

Bird, E. C. F.: Coastline Changes, A global review, Wiley, New York, NY, 1985.

Birnbaum, G. and Lüpkes, C.: A new parameterization of surface drag in the marginal sea ice zone, Tellus A, 54, 107-123, doi:10.1034/j.1600-0870.2002.00243.x, 2002.

Blunden, J. and Arndt, D. S. (Eds.): State of the climate in 2011, B. Am. Meterol. Soc., 93, S1-S264, 2012.

Brooks, S. M. and Spencer, T.: Temporal and spatial variations in recession rates and sediment release from soft rock cliffs, Suffolk coast, UK, Geomorphology, 124, 26-41, 2010. 
Brown, J., Jorgenson, M. T., Smith, O. P., and Lee, W.: Long-term rates of coastal erosion and carbon input, Elson Lagoon, Barrow, Alaska, Eighth International Conference on Permafrost, 21-25 July 2003, Zurich, Switzerland, 2003.

Cavalieri, D., Parkinson, P., Gloersen, P., and Zwally, H. J.: Sea Ice Concentrations from Nimbus-7 SMMR and DMSP SSM/ISSMIS Passive Microwave Data, 1979-2011, National Snow and Ice Data Center, 1996.

Clow, G. D., DeGange, A. R., Dirksen, D. V., and Zimmerman, C. E.: Climate change considerations, in: An Evaluation of the Science Needs to Inform Decisions on Outer Continental Shelf Energy Development in the Chukchi and Beaufort Seas, Alaska, edited by: Holland-Bartels, L. and Pierce, B., US Geological Survey Circular 1370, 81-108, 2011.

Coastal Engineering Research Center: Shore Protection Manual, US Army Engineer Waterways Experiment Station, Coastal Engineering Research Center, 1-652, 1984.

Comiso, J. C.: Warming trends in the Arctic from clear sky satellite observations, J. Climate, 16, 3498-3510, 2003.

Danard, M. B., Rasmussen, M. C., Murty, T. S., Henry, R. F., Kowalik, Z., and Venkatesh, S.: Inclusion of ice cover in a storm surge model for the Beaufort Sea, Nat. Hazards, 2, 153-171, 1989.

Dean, R. G. and Dalrymple, R. A.: Water Wave Mechanics for Engineers and Scientists, 2 Edn., World Scientific, Singapore, 1991.

Dean, R. G. and Dalrymple, R.: Coastal Processes with Engineering Engineering Applications, Cambridge University Press, 2004.

Eicken, H., Gradinger, R., Gaylord, A., Mahoney, A., Rigor, I., and Melling, H.: Sediment transport by sea ice in the Chukchi and Beaufort Seas: increasing importance due to changing ice conditions?, Deep-Sea Res. Pt. II, 52, 3281-3302, doi:10.1016/j.dsr2.2005.10.006, 2005.

Garbrecht, T., Lüpkes, C., Hartmann, J., and Wolff, M.: Atmospheric drag coefficients over sea ice - validation of a parameterisation concept, Tellus A, 54, 205-219, doi:10.1034/j.16000870.2002.01253.x, 2002.

Greenberg, J., Hart, P., and Grantz, A.: Bathymetric Map of the Continental Shelf, Slope, and Rise of the Beaufort Sea North of Alaska, US Geological Survey Miscellaneous Investigations Series Map 1182-A, 6 p., 1 sheet, scale 1 : 500,000, 1981.

Günther, F., Overduin, P. P., Sandakov, A. V., Grosse, G., and Grigoriev, M. N.: Short- and long-term thermo-erosion of ice-rich permafrost coasts in the Laptev Sea region, Biogeosciences, 10, 4297-4318, doi:10.5194/bg-10-4297-2013, 2013.

Henry, R. F.: Storm Surges, Institute of Ocean Sciences, Victoria, BC, 1-44, 1975.

Héquette, A., Desrosiers, M., and Barnes, P. W.: Sea ice scouring on the inner shelf of the southeastern Canadian Beaufort Sea, Mar. Geol., 128, 201-219, 1995.

Hoque, M. A. and Pollard, W. H.: Arctic coastal retreat through block failure, Can. Geotech. J., 46, 1103-1115, 2009.

IPCC: Climate change 2013: the physical science basis, in: Contribution of Working Group I to the Fifth Assessment Report of the Intergovernmental Panel on Climate Change, Cambridge University Press, 1535 pp., 2013.

Jones, E. P.: Circulation in the Arctic Ocean, Polar Res., 20, 139146, 2001.

Jones, B. M., Arp, C. D., Jorgenson, M. T., Hinkel, K. M., Schmutz, J. A., and Flint, P. L.: Increase in the rate and unifor- mity of coastline erosion in Arctic Alaska, Geophys. Res. Lett., 36, L03503, doi:10.1029/2008GL036205, 2009.

Jorgenson, M. T., Jorgenson, J. C., Macander, M., Payer, D., and E, M. A.: Monitoring of coastal dynamics at Beaufort Lagoon in the Arctic National Wildlife Refuge, Northeast Alaska, Reports on Polar and Marine Research, 413, 22-28, 2002.

Kobayashi, N.: Formation of thermoerosional niches into frozen bluffs due to storm surges on the Beaufort Sea coast, J. Geophys. Res., 90, 11983-11988, 1985.

Kobayashi, N., Vidrine, J. C., Nairn, R. B., and Soloman, S. M.: Erosion of frozen cliffs due to storm surge on Beaufort Sea Coast, J. Coastal Res., 15, 332-344, 1999.

Kovacs, A. and Sodhi, D. S.: Shore ice pile-up and ride-up: field observations, models, theoretical analyses, Cold Reg. Sci. Technol., 2, 210-288, 1980.

Kowalik, Z.: Storm surges in the Beaufort and Chukchi seas, J. Geophys. Res., 89, 10570-10578, 1984.

Lantuit, H. and Pollard, W. H.: Fifty years of coastal erosion and retrogressive thaw slump activity on Herschel Island, southern Beaufort Sea, Yukon Territory, Canada, Geomorphology, 95, 84102, 2008.

Lantuit, H., Overduin, P. P., Couture, N., Wetterich, S., Aré, F., Atkinson, D., Brown, J., Cherkashov, G., Drozdov, D., Forbes, D. L., Graves-Gaylord, A., Grigoriev, M., Hubberten, H. W., Jordan, J., Jorgenson, T., Ødegård, R. S., Ogorodov, S., Pollard, W. H., Rachold, V., Sedenko, S., Solomon, S., Steenhuisen, F., Streletskaya, I., and Vasiliev, A.: The Arctic Coastal Dynamics Database: A New Classification Scheme and Statistics on Arctic Permafrost Coastlines, Estuar. Coast., 35, 383-400, doi:10.1007/s12237-010-9362-6, 2012.

Lantuit, H., Overduin, P. P., and Wetterich, S.: Recent progress regarding permafrost coasts, Permafrost Periglac., 24, 120-130, doi:10.1002/ppp.1777, 2013.

Lesack, L. F. W., Marsh, P., Hicks, F. E., and Forbes, D. L.: Timing, duration, and magnitude of peak annual waterlevels during ice breakup in the Mackenzie Delta and the role of river discharge, Water Resour. Res., 49, 8234-8249, doi:10.1002/2012WR013198, 2013.

Lesack, L. F. W., Marsh, P., Hicks, F. E., and Forbes, D. L.: Local spring warming drives earlier river-ice breakup in a large Arctic delta, Geophys. Res. Lett., 41, 1560-1567, doi:10.1002/(ISSN)1944-8007, 2014.

Lintern, D. G., Macdonald, R. W., Solomon, S. M., and Jakes, H.: Beaufort Sea storm and resuspension modeling, J. Marine Syst., 127, 14-25, doi:10.1016/j.jmarsys.2011.11.015, 2011.

Lisitzin, E.: Sea-Level Changes, Elsevier Oceanography Series, 286 pp., New York, 1974.

Lynch, A. H., Lestak, L. R., Uotila, P., Cassano, E. N., and Xie, L.: A factorial analysis of storm surge flooding in Barrow, Alaska, Mon. Weather Rev., 136, 898-912, doi:10.1175/2007MWR2121.1, 2008.

Manson, G. K. and Solomon, S. M.: Past and future forcing of Beaufort Sea coastal change, Atmos. Ocean, 45, 107-122, doi:10.3137/ao.450204, 2007.

Mars, J. C. and Houseknecht, D. W.: Quantitative remote sensing study indicates doubling of coastal erosion rate in past $50 \mathrm{yr}$ along a segment of the Arctic coast of Alaska, Geology, 35, 583586, doi:10.1130/G23672A.1, 2009. 
Maslanik, J. A., Fowler, C., Stroeve, J., Drobot, S., Zwally, J., Yi, D., and Emery, W.: A younger, thinner Arctic ice cover: increased potential for rapid, extensive sea-ice loss, Geophys. Res. Lett., 34, L24501, doi:10.1029/2007GL032043, 2007.

Maslanik, J., Stroeve, J., Fowler, C., and Emery, W.: Distribution and trends in Arctic sea ice age through spring 2011, Geophys. Res. Lett., 38, L13502, doi:10.1029/2011GL047735, 2011.

Meier, W. N. and Stroeve, J.: Comparison of sea-ice extent and ice-edge location estimates from passive microwave and enhanced-resolution scatterometer data, Ann. Glaciol., 48, 6570, doi:10.3189/172756408784700743, 2008.

Moore, L. J. and Griggs, G. B.: Long-term cliff retreat and erosion hotspots along the central shores of the Monterey Bay National Marine Sanctuary, Mar. Geol., 181, 265-283, 2002.

Morton, R. A., Miller, T., and Moore, L.: Historical shoreline changes along the US Gulf of Mexico: a summary of recent shoreline comparisons and analyses, J. Coastal Res., 214, 704709, doi:10.2112/04-0230.1, 2005.

Murty, T. S. and Polavarapu, R. J.: Influence of an ice layer on the propagation of long waves, Mar. Geodesy., 2, 99-125, doi:10.1080/15210607909379342, 1979.

Overeem, I., Anderson, R. S., Wobus, C. W., Clow, G. D., Urban, F. E., and Matell, N.: Sea ice loss enhances wave action at the Arctic coast, Geophys. Res. Lett., 38, L17503, doi:10.1029/2011GL048681, 2011.

Rearic, D. M., Barnes, P. W., and Reimnitz, E.: Bulldozing and resuspension of shallow-shelf sediment by ice keels: implications for Arctic sediment transport trajectories, Mar. Geol., 91, 133147,1990

Reimnitz, E., Graves, S. M., and Barnes, P. W.: Beaufort Sea coastal erosion, shoreline evolution, and sediment flux, USGS Open File Report 85-380, 1985.

Reimnitz, E., Graves, S. M., and Barnes, P. W.: Beaufort Sea coastal erosion, sediment flux, shoreline evolution, and the erosional shelf profile, USGS Map 1182-G, 1988.

Rickets, M.: Hydrographic Survey H07921 of Smith Bay, US Coast and Geodetic Survey, ARW-4251, 1953.

Sadler, P. M.: Sediment accumulation rates and the completeness of stratigraphic sections, J. Geol., 89, 569-584, 1981.

Sepp, M. and Jaagus, J.: Changes in the activity and tracks of Arctic cyclones, Clim. Change, 105, 577-595, doi:10.1007/s10584010-9893-7, 2011.

Serreze, M. C. and Barrett, A. P.: Characteristics of the Beaufort Sea high, J. Climate, 24, 159-182, doi:10.1175/2010JCLI3636.1, 2011.

Serreze, M. C. and Barry, R. G.: The Arctic Climate System, Cambridge University Press, New York, 2005.
Serreze, M. C., Holland, M. M., and Stroeve, J.: Perspectives on the Arctic's shrinking sea-ice cover, Science, 315, 1533-1536, doi:10.1126/science.1139426, 2007.

Sessford, E.: Spatial and temporal analysis of Holocene coastal development: applications to erosion assessment and cultural heritage mitigation in Svalbard, $\mathrm{Ph}$ D. thesis, University of Oslo, 2013.

Solomon, S. M.: Spatial and temporal variability of shoreline change in the Beaufort-Mackenzie region, Northwest Territories, Canada, Geo-Mar. Lett., 25, 127-137, doi:10.1007/s00367-0040194-x, 2005.

Squire, V. A.: Of ocean waves and sea-ice revisited, Cold Reg. Sci. Technol., 49, 110-133, doi:10.1016/j.coldregions.2007.04.007, 2007.

St-Hilaire-Gravel, D., Forbes, D. L., and Bell, T.: Multitemporal analysis of a gravel-dominated coastline in the Central Canadian Arctic Archipelago, J. Coastal Res., 28, 421-441, doi:10.2112/JCOASTRES-D-11-00020.1, 2012.

Stammerjohn, S., Massom, R., Rind, D., and Martinson, D.: Regions of rapid sea ice change: An inter-hemispheric seasonal comparison, Geophys. Res. Lett., 39, L06501, doi:10.1029/2012GL050874, 2012.

Urban, F. E. and Clow, G. D.: Air temperature, wind speed, and wind direction in the National Petroleum Reserve-Alaska and the Arctic National Wildlife Refuge, 1998-2011, US Geological Survey Open File Report 2013-1063, 2013.

Urban, F. E. and Clow, G. D.: DOI/GTN-P climate and active-layer data acquired in the National Petroleum Reserve - Alaska and the Arctic National Wildlife Refuge, 1998-2011, US Geological Survey Data Series 812, doi:10.3133/ds812, 2014.

Vasiliev, A., Kanevskiy, M., Cherkashov, G., and Vanshtein, B.: Coastal dynamics at the Barents and Kara Sea key sites, GeoMar. Lett., 25, 110-120, doi:10.1007/s00367-004-0192-z, 2005.

Wadhams, P., Squire, V. A., Goodman, D. J., Cowan, A. M., and Moore, S. C.: The attenuation rates of ocean waves in the marginal ice zone, J. Geophys. Res.-Sol. Ea., 93, 6799-6818, 1988.

Wobus, C., Anderson, R., Overeem, I., Matell, N., Clow, G., and Urban, F.: Thermal erosion of a permafrost coastline: improving process-based models using time-lapse photography, Arct. Antarct. Alp. Res., 43, 474-484, doi:10.1657/1938-424643.3.474, 2011.

Zagórski, P.: Shoreline dynamics of Calypsostranda (NW Wedel Jarlsberg Land, Svalbard) during the last century, Polish Polar Res., 32, 67-99, doi:10.2478/v10183-011-0004-x, 2011. 